\title{
Problems with glow plug - a review
}

ARTICLE INFO

Received: 5 June 2021

Revised: 7 July 2021

Accepted: 9 July 2021

Available online: 25 July 2021
Despite the development of hybrid and electric vehicles, a many-million population of cars with combustion engines, and particularly CI engines occurs on the roads. Also, many stationary CI engines are still utilized. Despite their improved technologies and characteristics the modern CI engines negatively affect an environment due to cold starting problems. Below $0^{\circ} \mathrm{C}$, engine starts are problematic due to the decreased battery performance and the spray characteristics, the increased ignition delay time, and the engine oil viscosity. Therefore, various glow plugs are applied to facilitate this process. Types, features, and applications of glow plugs in various engines have been discussed in the paper. One case of failure of glow plug has been presented in the article, including the cause of it.

Key words: CI engine, glow plug, failure

This is an open access article under the CC BY license (http://creativecommons.org/licenses/BY/4.0/)

\section{Introduction}

Despite the improved technologies, higher torques, and performance characteristics in modern $\mathrm{CI}$ engines they have still a negative environment effects related to cold starting problems. Reaching values close to $0^{\circ} \mathrm{C}$ by the temperature of ambient air and engine cylinder block and head, engine starting is problematic due to the weakening of the battery performance and the spray characteristics, enhancement of the ignition delay time and of the engine oil viscosity. Therefore, various auxiliary devices are used to facilitate this process. Lindl and Schmitz [53] reviewed various starting aids and their utility in the modern diesel engine. According to them, glow plugs, and intake air heaters provide at ambient temperatures below $263 \mathrm{~K}$ a reliable start and low pollutant emission levels. They found that the BERU glow plugs exhibited a very durable effect in a form of a self-regulating- or an electronically controlled- a cold start. They reported the glow plug development allowing combustion process control via ion current sensing. They informed that electric intake air heaters were useful in a wide displacement range. Intake manifold burners proved their application to large displacement engines and at arctic temperatures.

Therefore, the often application of glow plugs relates to the cold start of various engines.

Toedter et al. [81] stated that the glow strategy must be a compromise between driving comfort and fuel consumption resulting from the glow system power demand. The required glow output of the application at various operating points depends on the engine concept and the overall calibration strategy. While intelligent glow systems can be adapted to the engine strategy, they also influence the fuel consumption and pollutant emissions. The use of algorithms minimizing current changes and power losses allows a precise set of the glow power of the application at the desired level.

Glow plugs are designed to reach their saturation temperature after a specific period at a given voltage range. Such a temperature should be maintained for a specific period to provide stable combustion conditions. Diesel engine operation and its toxic emissions can only be im- proved if the glow plug matches or exceeds the engine thermal requirements [62].

According to [7], in the modern direct injection, diesel engine a glow plug projects into the main combustion chamber and helps with ignition during the start. The heating element of a modern glow plug reaches a temperature above $1,000^{\circ} \mathrm{C}$ within a few seconds.

Hasegawa et al. [36] stated that glow plugs are designed for cold start assist in diesel engines, and their use for cold start has been widely investigated. They explained that to improve fuel consumption, exhaust emission and maximum power diesel engines demand a lower compression ratio. However, the latter may cause combustion instability issues under cold conditions. Based on results of numerical simulation the authors found that the appropriate controlling of an equivalence ratio and temperature surrounding glow plug by multiple pilot injections allow improving combustion stability under cold start conditions.

Çelik et al. [20] noticed that to minimize the mentioned cold starting problems, various glow plugs are commonly used in the combustion chamber. Such electric heaters enhance the temperature of air in the combustion chamber for about 2 or $3 \mathrm{~s}$ before the engine starts. However, being heater in this chamber causes some other problems after the engine starts. Glow plugs modify the flow characteristics of air and fuel spray in the chamber.

According to Pszczolkowski and Kolinski [72] the effect of CI engine speed on its start-up processes can be described for characteristic speed values: the minimum one, the optimal one, the maximum one, as well as the necessary one and the limit one. In the flat coordinate system: temperature-rotational speed of the crankshaft, you can determine the so-called 'engine starting areas' where the engine exhibits its specified starting characteristics. These areas are limited by the engine start curves. If, in the aforementioned coordinate system, the dependence of the engine crankshaft rotational speed forced by its starting system on temperature is presented, its points of intersection with the engine start-up curves determine the values of the lowest engine start-up temperature using various methods. These points 
allow defining the actual starting properties of a combustion engine, including the type of necessary starting devices, such as glow plugs, in the given temperature conditions of engine operation.

Kolinski and Pszczolkowski [49] studied the starting characteristics of a 4CT90 CI engine. The quantities characterizing the start-up and subject to direct measurement include: the intensity of the current drawn from the battery by the glow plugs and the starter, the voltage at the terminals and the average value of the speed forced by the starter.

According to Rudolph et al. [74] the use a compression ratio (CR) of 16.5 in the engine VW 2.0 TDI CR (2008) could create problems with starting a cold engine. Therefore, an increased power starter was applied, providing an engine speed of $450 \mathrm{rpm}$ during a cold start. Additionally, glow plugs with a metal heating core were used.

Wos P. et al. [84] reported that the use of a reduced CR weakened the engine's starting capacity and caused the phenomenon of misfiring (ignitability problem), especially during start-up and in the initial phase of engine warm-up. Therefore, to facilitate starting the SkyActiv-D engine was equipped with the efficient ceramic glow plugs located in the combustion chamber and the appropriate fuel injection strategy was adapted.

The goal of the paper was to discuss types, features, and applications of glow plugs in various engines.

Interestingly, [39] explained that particulate filters must be regenerated in various, sometimes critical driving conditions, such as a slow driving around the city. This reliable regeneration is made possible by the Emcon Technologies fuel evaporator, which feeds the hydrocarbons contained in the diesel vapors directly into the exhaust system. There they react in the catalytically coated element and generate the heat required to initiate active regeneration of the Diesel Particulate Filter (DPF). Usually, liquid diesel fuel is fed to the evaporation chamber by means of a pump or, if there is sufficient pre-pressure, through a valve, where the fuel is heated and vaporized by means of a special glow plug. Fuel in the form of vapor is added to the exhaust gas and mixed there. Such a system is characterized by a simple and easily adaptable design and enables optimal mixing of fuel and exhaust gases.

The similar utilization of special glow plug for fuel evaporator was reported in [17]. A similar concept was also adapted by Karsten et al. [47].

Recently, there has also been interest in the use of glow plugs in hybrid vehicles. The glow plugs are used in combustion engines that are part of a hybrid drive system.

The method for controlling glow behavior of heater plugs of diesel engine for use in hybrid vehicle was described in [46].

Merkisz et al. [58] suggested that the catalyst-covered glow plugs of various lengths of the heating part can be applied in hybrid powertrains where sequential engine activation is used.

\section{Types of glow plugs}

According to Kita et al. [48] there are the following types of glow plugs:

1) Conventional glow plugs need a preheating time of 20-30 s before their operation. If such a time is too short their durabilities weak, their resistance levels of the heater decrease reduce, and a strong electric currents flow in their circuits. Due to them, the heaters quickly reach a high temperature. As a solution to this problem, a control system for the electric current was introduced to protect the heater. Such quick-heating glow plugs showed to be expensive, and the shortening of their preheating time to less than $6 \mathrm{~s}$ was practically impossible due to the heaters were made of metal.

2) Ceramic-type glow plugs comprise a ceramic heating element in the heating section. Silicon nitride is predestined for glow plugs as it exhibits high resistance to heat, corrosion, and thermal shock and higher strength at high temperatures than metals. Therefore, it retains its strength under its exposition to a high-temperature flame in a combustion chamber. The lack of corrosion due to oxidation under the intense oxidation-reduction atmosphere in combustion gases, also enhances its durability. The application of ceramic glow plugs is recommended by a superior heating profile and a high-temperature after-glow. A ceramic glow plug can be heated to $800^{\circ} \mathrm{C}$ in $2 \mathrm{~s}$, which significantly shortens the preheating time. The temperature can be maintained at $900^{\circ} \mathrm{C}$ for a long time after starting, which purifies engine emissions. Therefore, the plugs provide an afterglow system. With these glow plugs, diesel engines can now be started in the same manner as gasoline ones.

A ceramic glow plug using silicon nitride ceramics for the heater body developed in 1981 by Isuzu Motors are much better than metal glow plugs and firmly established in the market as auxiliary starter equipment for diesel engines. Such glow plugs achieve a high temperature of $1500^{\circ} \mathrm{C}$ in the after-glow mode, allowing an effective reduction of white smoke. The durable ceramic glow plug also enhances the engine performance, and reliability.

In 1990 Bosch developed Duraterm glow plug technology allowing obtaining a preheating time below 4 seconds, and a post-glow time of up to 180 seconds. The mentioned plugs became much slimmer and, in some cases, also longer compared to earlier versions. In 2004 Bosch introduced low-voltage Duraterm High Speed glow plugs characterized with an improved cold-idling and doubling of the post-glow time to 360 seconds. In 2006 Bosch introduced DuraSpeed glow plugs for diesel engines with low compression ratios $(\varepsilon=15: 1)$. These self-regulating, ceramic glow plugs allowed for preheating temperatures of up to $1,300^{\circ} \mathrm{C}$ within 2 seconds [71].

Some older engine designs even need a preheating period after a relatively short time-period of rest [62].

Conventional preheating systems utilized Duraterm glow plugs with a nominal voltage of 11 volts, actuated with the electrical system voltage [71].

The newer low-voltage preheating systems utilized glow control units/software and glow plugs with nominal voltages below 11 volts and made of:

- metal: Duraterm High Speed for $\varepsilon \geq 18: 1$

- ceramic: DuraSpeed for $\varepsilon \leq 17: 1$ [71].

Modern diesel engines often need the 'post-glow' function of the glow plugs to help further decrease emissions [62].

Some parameters of various glow plugs chosen were presented in Table 1. 


\begin{tabular}{|c|c|c|c|c|c|c|c|c|c|c|}
\hline Designation & Type & $\begin{array}{c}\text { Voltage } \\
\text { [V] }\end{array}$ & $\begin{array}{c}\text { Time for } \\
\text { readiness } \\
\text { to start } \\
\text { [s] }\end{array}$ & $\begin{array}{c}\text { Start } \\
\text { time at } \\
-28^{\circ} \mathrm{C} \\
{[\mathrm{s}]}\end{array}$ & $\begin{array}{c}\text { Postglow } \\
\text { time } \\
\text { [min] }\end{array}$ & $\begin{array}{c}\text { Postglow } \\
\text { temperature } \\
{\left[{ }^{\circ} \mathrm{C}\right]}\end{array}$ & \begin{tabular}{|} 
Warm-up \\
time to \\
$1,000^{\circ} \mathrm{C}$ \\
{$[\mathrm{s}]$}
\end{tabular} & $\begin{array}{c}\text { Maximum } \\
\text { preheating } \\
\text { temperature } \\
{\left[{ }^{\circ} \mathrm{C}\right]}\end{array}$ & $\begin{array}{l}\text { CR } \\
{[-]}\end{array}$ & Refs \\
\hline $\begin{array}{l}\text { Bosch } \\
\text { Duraterm }\end{array}$ & Metal & 11.0 & $<4$ & 15 & $<3$ & 1,000 & $<6$ & 1,150 & $\geq 20$ & [71] \\
\hline $\begin{array}{l}\text { Bosch } \\
\text { Duraterm High } \\
\text { Speed }\end{array}$ & Metal & $4.4 / 5.0$ & $<2$ & $<10$ & $<6$ & 1,000 & $<3$ & 1,100 & $\geq 18$ & [71] \\
\hline $\begin{array}{l}\text { Bosch } \\
\text { DuraSpeed }\end{array}$ & Ceramic & 7.0 & $<1$ & 2 & $<15$ & 1,200 & $<2$ & 1,300 & $\leq 17$ & [71] \\
\hline BERU GE & $\begin{array}{l}\text { Sheathed with two- } \\
\text { filaments, electroni- } \\
\text { cally controlled }\end{array}$ & $<5$ & n.a. & $2\left(24^{\circ} \mathrm{C}\right)$ & n.a. & n.a. & n.a. & n.a. & n.a. & [30] \\
\hline BERU GN & $\begin{array}{l}\text { Sheathed with two- } \\
\text { filaments }\end{array}$ & $<13.5$ & n.a. & n.a. & n.a. & n.a. & n.a. & n.a. & n.a. & [30] \\
\hline BERU GV & $\begin{array}{l}\text { Sheathed with } \\
\text { two/one filaments }\end{array}$ & 11 & $5-7$ & n.a. & n.a. & n.a. & n.a. & n.a. & n.a. & {$[30]$} \\
\hline BERU GF & Flame & $12 / 24$ & $15-50$ & n.a. & $<6$ & n.a. & n.a. & n.a. & n.a. & {$[30]$} \\
\hline BERU GD & Wire-filament & n.a. & n.a. & n.a. & n.a. & n.a. & n.a. & n.a. & n.a. & [30] \\
\hline BERU GH & Sheathed or filament & n.a. & n.a. & n.a. & n.a. & n.a. & n.a. & n.a. & n.a. & {$[30]$} \\
\hline BERU CPG & $\begin{array}{l}\text { Sheathed with } \\
\text { ceramic heating } \\
\text { element, effective } \\
\text { external heater, } \\
\text { electronically con- } \\
\text { trolled or regulated }\end{array}$ & $\begin{array}{l}5.4,6.2,7 \text { or } \\
\text { regulated by the } \\
\text { control module }\end{array}$ & n.a. & n.a. & n.a. & n.a. & n.a. & n.a. & n.a. & {$[30]$} \\
\hline BERU PSG & $\begin{array}{l}\text { Sheathed with two } \\
\text { filaments, electroni- } \\
\text { cally controlled, } \\
\text { with built-in pres- } \\
\text { sure sensor }\end{array}$ & $\begin{array}{c}4.4 \text { or } 4.6 \text { or } \\
\text { controlled by the } \\
\text { heating time } \\
\text { control unit. } \\
\text { Sensor supply } 5\end{array}$ & n.a. & $2\left(24^{\circ} \mathrm{C}\right)$ & n.a. & n.a. & $1-2$ & n.a. & n.a. & {$[7,30]$} \\
\hline DENSO & Instant heating & 11 & 2.5 & n.a. & n.a. & 970 & 2 & 1,050 & n.a. & [77] \\
\hline DENSO & $\begin{array}{l}\text { Extended post- } \\
\text { heating }\end{array}$ & 11 & $<10$ & n.a. & n.a. & $1,050-970$ & 7.5 & 1,050 & n.a. & [77] \\
\hline DENSO & Double Coil & 11 & 10 & n.a. & n.a. & 1,050 & $<6$ & 1,150 & n.a. & $\begin{array}{l}76, \\
77]\end{array}$ \\
\hline DENSO & Ceramic & 11 & $<6$ & n.a. & n.a. & & $<4$ & 1,250 & n.a. & [77] \\
\hline NGK Standard & $\begin{array}{l}\text { Sheathed metal with } \\
\text { single coil }\end{array}$ & 12 & 20 & n.a. & n.a. & 1,050 & $<35$ & 1,050 & n.a. & [61] \\
\hline $\begin{array}{l}\text { NGK Rapid } \\
\text { Glow }\end{array}$ & $\begin{array}{l}\text { Sheathed metal with } \\
\text { single coil }\end{array}$ & 12 & $13-17$ & n.a. & n.a. & 1,050 & $<25$ & 1,050 & n.a. & {$[61]$} \\
\hline NGK QGS & $\begin{array}{l}\text { Sheathed metal with } \\
\text { single coil }\end{array}$ & 12 & 6 & n.a. & n.a. & 900 & n.a. & 900 & n.a. & [61] \\
\hline NGK SRM & $\begin{array}{l}\text { Sheathed metal with } \\
\text { two coils }\end{array}$ & 12 & $<6$ & n.a. & n.a. & 900 & & 1,050 & n.a. & [61] \\
\hline $\begin{array}{l}\text { NGK } \\
\text { NHTC }\end{array}$ & $\begin{array}{l}\text { Sheathed metal with } \\
\text { two coils }\end{array}$ & 12 & $<2$ & n.a. & 10 & n.a. & $<2$ & 1,300 & n.a. & [61] \\
\hline NGK SRC & $\begin{array}{l}\text { Ceramic with two } \\
\text { coils }\end{array}$ & 12 & $<3$ & n.a. & n.a. & n.a. & $<6$ & 1,200 & n.a. & [61] \\
\hline
\end{tabular}

\subsection{Glow plugs for older engines}

\section{Glow plug with only pre-heating (Type GV)}

Older diesel engines are equipped with 2-phase glow plugs that only glow before and during the start phase. In case of BERU glow plugs, their abbreviation is GV [7], [30]. The BorgWarner sheathed glow plug with a 2-coil technology (type GV) utilized in such engines provides:

- reliable cold starting

- pre-heating time of 5-7 seconds [78].
Such glow plugs possessed one or two filaments. After the engine has started, such glow plugs are switched off. As they are only designed for a low operating voltage, they can only be fitted when prescribed by the manufacturers [30].

\section{Glow plug for flame start systems (Type GF)}

BERU developed the Flame Start System technology utilizing Flame Glow Plug (CV) providing for the diesel engines:

- quick starting even at low temperatures 
- short pre-heating time (only 15 to 20 seconds)

- long post-flame time (up to 6 minutes)

- availability for $12 \mathrm{~V}$ and $24 \mathrm{~V}$ versions.

Flame Glow Plugs (CV) are Fitted with the Instant Start System 2nd generation, allowing improved starting capability at low temperatures [22].

Such glow plugs were predestined for large-volume DI diesel engines.

After reaching the glow temperature, additional fuel entered the evaporation zone of such a flame glow plug via a valve resulting in the generation of a flame permanently warming the inlet air [30].

\section{Glow plugs for auxiliary heaters $(\mathrm{GH})$}

Many car drivers benefit from auxiliary heaters based on BERU type GH glow plugs providing comfort in winter particularly under icy cold, through making the cars warm on entry and eliminating an ice scraping. The BERU Auxiliary Heaters comprise the sheathed or coil glow plugs. There are available versions meeting the demands of auxiliary heaters in gasoline or diesel cars alike [22, 30].

Glow plug with wire filament as heater element (Type GD)

Older diesel vehicles such as tractors, tow trucks and construction machines, as well as in stationary engines require glow plugs with a wire filament (Type GD). Such glow plugs generate the heat necessary for the engine starting thanks to a wire filament acting as the heating element. Such glow plugs stand out by a robust design and a high resistance to heavy vibrations both in one- and two-pin versions [22, 30].

NGK manufactured several types of metal sheathed glow plugs [61] including:

- Standard possessing single coil heated at a uniform rate to its maximum temperature $1050^{\circ} \mathrm{C}$ with a constant current consumption. The pre-heating time is of $20 \mathrm{~s}$.

- Rapid Glow possessing single heating coil allowing a higher current flow initially to promote a faster heating time. As the temperature increases the resistance of coils increases to restrict the current flow. The preheating time is of 13-17 s.

- Quick Glow System (QGS) with a heating coil allowing very high current flow as soon as it is energized. As a result of its extremely quick heating such a plug needs strict regulation and is only used together with a predestined QGs control system. The pre-heating time is of $6 \mathrm{~s}$.

- Advanced Quick Glow System (AQGS) is an evolution of the QGS type. It possesses very high-performance characteristics allowing faster heating time than that of either the SRM or QGS types. The system comprises two coils designed to operate at the battery voltage at the very short pre-heating stage, approximately 6.5 volts during cranking and 5.0 volts in the post glow period. Due to the high inrush current and the specific stages of applied voltage, the system needs very precise control by PWM (pulse width modulation) via the ECU, which additionally allows a decrease in harmful emissions/smoke [62].

DENSO manufactured glow plugs in various technologies including single coil, double coil, extended postheating, ceramic glow plugs and instant heating. The Denso glow plug has the outer casing and terminal zinc coated to resist corrosion. It possesses also an insulating disc preventing short circuits, an alloy casing, a rubber seal is in place to prevent air from seeping through and corroding the coil. The electrical insulation of the coil is provided by the packed heat-conductive magnesium oxide powder. The glow plug posses two coils: the regulation one and the heating one. The regulating coil being the main one controls and sustains temperature rise and ensures a rapid warm-up. The heating and regulating coils are connected using laser welding to always maintain their position and ensure consistent resistance characteristics. The shorter, tapered heating coil inside the end of the glow plug provides a quick start below 3 seconds even in cold conditions. It can then hold its post-heating temperature for up to six minutes after a cold start. This allows weakened engine emissions. The narrowed glow plug tip ensures improved heating efficiency and excellent performance [77].

BERU manufactured several types of glow plugs for modern diesel engines. One of them comprises the selfregulating pencil type glow plugs, and particularly postheating pencil type glow plugs [7]

\subsection{Self-regulating pencil type glow plugs}

\section{Glow plug with pre-heating - start heating - post-heating (Type GN)}

The BERU glow plugs applied in modern diesel engines possess abbreviation GN [30]. They are equipped with the 3-phase glow system and glow:

- before the start

- during the start phase

- after the start, and

- during engine operation (in coasting mode).

The electronically controlled pre-heating begins when the ignition lock starter switches on and lasts 2-5 seconds at normal outside temperatures until the engine reaches start readiness. The post-heating time is up to 3 minutes after the engine start to minimize pollutant and noise emissions.

The post-heating process is continued until the engine coolant reaches a temperature of $70^{\circ} \mathrm{C}$, or the engine is switched off after a certain time set in the performance map. No post-heating occurs if the engine coolant temperature is higher than that before starting.

With the temperature enhancement, self-regulating glow plugs limit the current flowing from the battery to the plug to prevent its overheating. However, during the engine operation, the voltage can rise to a point where glow plugs with characteristics not complied with manufacturer recommendations can blow. After the engine start, the plugs supplied with current are exposed to high combustion temperatures and are heated up. The post-heating BERU glow plugs are functional at full generator voltage. Their temperature enhances very quickly but is then limited by the regulating coil to a saturation temperature that is lower than that of non-post-heating plugs.

The reduced diameter at the front end of the heating rod in the post-heating BERU GN glow plug allowed decreasing the glow time to $2-5$ seconds. At a temperature of $0^{\circ} \mathrm{C}$, the heating rod starts glowing just 2 seconds before the engine start. For the lower temperatures, the system is 
adapted to the requirements by the glow-time control, and glow time enhances at $-5^{\circ} \mathrm{C}$ approx. 5 and at $-10^{\circ} \mathrm{C}$ approx. 7 seconds, respectively.

Until the reaching of an ideal ignition temperature, the so-called white or blue smoke is emitted from the exhaust as the result of incomplete combustion of the fuel at too low an ignition temperature. Post-heating allows a more complete and less-noise burning of the diesel fuel during the warm-up phase, which decreases smoke opacity by up to $40 \%$.

Pre-heating and post-heating of GN glow plugs ensure that the diesel engine reaches the operating temperature quicker without characteristic knocking during its coldstart. Such knocking is caused by the abrupt fuel ignitions resulted from an increased ignition delay when the engine is cold [7].

Such glow plugs are predestined for vehicles with heating system capable of post-heating [30].

Glow plugs electronically controlled, with pre-heating start heating-post-heating (Type GE)

BERU elaborated the Instant Start System (ISS) comprising an electronic glow plug control unit and performance-optimized glow plugs with a limited heat-up time (up to 2 seconds) in comparison to up to 5 seconds for a standard glow plug (SR). Both in the heating-up and in the saturation phase, such plugs required much less energy. The control unit utilized power semi-conductors as switches controlling the glow plugs, replacing the earlier electromechanical relay. In comparison to the conventional selfregulating glow plugs, the winding combination of the power-optimized glow plug of the ISS was much shorter and the glowing area was weakened to one-third. In DI engines, this corresponded to the part of the heating rod protruding into the combustion chamber [7].

ISS ensures a spontaneous "gasoline engine" key start, stable idling, clean load acceptance and low emissions even at temperatures as low as minus $25^{\circ} \mathrm{C}$ [42].

Also, according to [14P] BERU AG considered the increasingly stringent emission limits and efforts to further reduce fuel consumption when further developing the Instant Start System (ISS).

Under engine operation, the glow plug is cooled by the charge variations and air movement in the compression phase. While a constant voltage of glow plug, its temperature weakens with enhanced speed for a constant injection quantity and enhances for a rising injection quantity and constant speed. The electronic control unit of ISS compensates for these effects providing a supply of the glow plugs with the optimal effective voltage for the respective operating point. The glow plug temperature is thus controlled depending on the operating state. The combination of the low voltage glow plug and the electronic control unit allows a very quick heating up of the glow plugs. This is done by supplying the full on-board voltage to the glow plug for a pre-defined period, and then operating only with the necessary effective voltage during synchronized operation. The normal pre-heating period is thus weakened to below 2 seconds even at low temperatures [7].

The high efficiency of the ISS system allowed the power taken from the on-board power supply to be comparable with that required by the glow plug. The control of each glow plug by a separate power semiconductor in the ISS allows separate monitoring of the current in each glow current circuit and thus an individual diagnostic at each plug [7].

Such glow plugs are predestined for engines of the latest generation with electronic heating time control [30].

NGK manufactured Self-Regulating Metal (SRM) sheathed glow plug containing two coils. The heating coil at the tip of the probe provides the heat source, while the regulating coil allows an extremely fast warm up time of temperature more than $900^{\circ} \mathrm{C}$ and after reaching that temperature maintains a high final temperature allowing longer post heating times [61].

\subsection{Ceramic glow plug (BERU CGP and Bosch DuraSpeed, NGK SRC, HTC, AQGS)}

BERU elaborated also ceramic glow plugs using a high strength $\mathrm{Si}_{3} \mathrm{~N}_{4}$ ceramic to enclose the electrically conductive $\mathrm{MoSi}_{2}$ inside an interpenetrating structure. Such a material withstands pressures up to 200 bar and temperatures up to $1,300^{\circ} \mathrm{C}$ in the various gaseous atmospheres inside the combustion chamber (ambient air, diesel, oxygen, water) $[7,30]$.

The ceramic heating elements were obtained in an extrusion and injection molding process followed by relieving, sintering, and hardening them to provide the tight tolerances needed before fitting into the metal bodies. This was accompanied by several diamond tool-based grinding procedures due to the extreme hardness and strength of the materials. The ceramic heating rod contacts were obtained in special high-temperature procedures over the full surface. This provided a high resistance capacity against oscillations and temperature changes [7, 30].

Apart from short heat-up times, the externally positioned heating rod design provided optimized regulation. It was electronically controlled or electronically regulated. The ceramic glow plug's heating capacity concentrated at the tip of the ceramic element needed less energy to generate the temperature necessary to engine start and thus less fuel consumption in comparison to the conventional plugs [7, 30].

Save the enhanced operating reliability, the resistance within the regulation system of such a glow plug provided its optimal energy balance at every engine operating point, resulting in a decrease in fuel consumption and emissions [71].

Such glow plugs are predestined for modern high-speed diesel engines with electronic heating time control or electronic heating time and temperature control [30].

When operating using a power amplifier, controlled by a microprocessor, the necessary engine heating is adjusted via a stored parameter profile. When using a closed-loop control module (CM), a necessary temperature from the engine control unit is fed into the CM, which then controls the CGP to the correct temperature. In both cases, the evaluation of engine load, speed, temperature, fuel flow, and other parameters is needed. The use of such glow plugs allows engine key-start together with a decreased pollutant emissions and with support during regeneration heating in the soot particle filter [30]. 
The ceramic heating element allowed increasing surface temperatures and extending the heating time. However, such glow plugs achieved full performance capabilities with the appropriate control units provided and became quickly damaged without observation of that requirement [30].

The Bosch DuraSpeed glow plugs possessed the heating element made of highly temperature-resistant $\mathrm{Si}_{3} \mathrm{~N}_{4}$ ceramic material forming, together with a flexible moldable metal tube, the so-called heater. This flexible design enhanced the mechanical durability of the glow plug, particularly under bending due to incorrect, slanted insertion in the workshop. The ceramic material also provided high hot-gas resistance and durability. Low-voltage technology weakened warm-up time and protected the battery. The electronic glow control unit connected to the EDC (Electronic Diesel Control) adapted the voltage for such glow plugs to the preheating temperature required by the engine. To reach such a temperature, the glow plugs could operate at enhanced voltages during warm-up, which was especially beneficial in extremely cold conditions. Additionally, such glow plugs reached their optimal preheating temperature even during drops in the electrical system voltage during the cold start [71].

Also, NGK elaborated several types of ceramic glow plugs encased in $\mathrm{Si}_{3} \mathrm{~N}_{4}$ characterized by a very high thermal conductivity and able withstanding very rapid heating times over extended service periods. The robust nature of the heating coil and the ceramic materials allow the prolonged post-glow times of up to ten minutes. The cross-sectional area heating portion of ceramic glow plugs can be much smaller. The combination of heating coil and ceramic coating applied in ceramic type glow plugs allows reaching higher temperatures than these for metal sheathed-type glow plugs [62].

- Self-Regulating Ceramic (SRC) type containing two coils and capable of reaching temperatures more than $1,000^{\circ} \mathrm{C}$. Such type utilizes metal heating coil. Such plugs provide the highest protection against the prolonged high temperatures involved with extended post-heating periods. They also withstand the high degree of thermal shock resulting from ultra quick heating times [62].

- High Temperature Ceramic (HTC) type uses a ceramic heating element [62].

- New-High Temperature Ceramic utilizes an all-ceramic heater. It reaches a temperature of $1,000^{\circ} \mathrm{C}$ in less than two seconds and uses post-glow time for more than ten minutes at temperatures of up to $1,350^{\circ} \mathrm{C}$. Optimal combustion is assured even with low compression ratios. It can glow intermediately to prevent cooling of the particle filter in deceleration phases [62].

\subsection{PSG pressure sensor glow plugs}

BERU elaborated also glow plugs with the built-in piezoresistive pressure sensors for continuous measurement of the combustion pressure [15]. The heating rods were not pressed in the glow plug bodies, as was the standard in the past. Instead, they were supported elastically as mobile components and transmitted the pressure to the diaphragms located in the rear area of the glow plugs. Thus, the actual pressure sensors were positioned far away from the combustion chamber. Thermal load on the seals remained controllable due to the use of heating rods from the BERU
Diesel ISSs only glowing at their tips. These PSGs were tested as original equipment by Volkswagen group and GM/Opel and can be used in the latest diesel engine designs.

Such glow plugs are predestined for diesel engines with electronic heating time control and control circuit, in which the combustion pressure is used to correct injection. The heating requirement of such an engine is adapted by a parameter profile stored in the ISS microcontroller and affected by load, speed, temperature, and fuel flow. ISS enables a spontaneous "combustion engine" key start-up to minus $15^{\circ} \mathrm{C}$ and minimizes the emission of pollutants is minimized.

At the same time, the axially movable heating rod with integrated electronics continuously transfers the in-cylinder pressure to the engine control unit as a ratiometric voltage signal enabling precise combustion control [30].

According to [15], the described technology can be implemented without problems not only with the steel ISS glow plugs, but also with the BERU ceramic glow plug.

Burrows et al. [18] reported that to allow developing the optimization of the combustion process, a closed-loop control strategy with precise feedback on the actual pressure in the combustion chamber is required as part of the engine control strategy. Siemens VDO Automotive elaborated an integrated glow plug pressure sensor all the way to an advanced prototype. This durable pressure sensor allowed direct pressure measurement and its integration into a glow plug with a ceramic heating element.

Graglia et al. [32] reported that General Motors developed a diesel engine management system with closed-loop injector control and integrated glow plug electronics. Such a control unit monitors and controls the combustion process in real time by means of glow plugs with a pressure sensor. Combustion control is necessary for the implementation of combustion strategies such as high premix or very lean combustion. Such strategies enable further emission reductions with the same or even lower fuel consumption and combustion noise. Moreover, the mentioned closed-loop control compensates for changes due to system wear and different fuel properties. This enables optimal combustion and low emissions throughout the entire life cycle of the engine.

According to [25] cold start conditions for a diesel engine affect the starting time, acoustics and emissions levels, and the smooth running of the engine. Due to the tendency to limit the CRs in diesel engines due to the need to reduce their emissions, there is an increasing need for efficient processes to ensure cold starting and optimize cold idling. The positive effect of high glow temperatures on combustion stability and the need for short heating times determine the further development of glow systems. The use of steered ceramic glow plugs introduced a new degree of freedom in diesel engine applications. The field of application of these plugs ranges from cold start support to emission reduction. The different temperature requirement profiles contrast with the glow plug service life and energy requirements. Therefore, it has been found that the ability to determine the glow temperature has the potential to optimize the glow strategy in cold start applications. 
Puente León et al. [73] studied the possibility of the application of a ceramic glow plug installed as standard not only as an actuator but also as a sensor for determining the speed of a DI diesel engine. The thermoelectric sensitivity of the ceramic glow plug to its environment was used. Such a process developed needed neither additional hardware nor specifications.

According to Pielecha et al. [68] an in-cylinder catalyst applied on glow plugs allowed counteracting the production of pollutants at the source. The use of an in-cylinder catalyst (on glow plugs) during diverse engine operating conditions decreased by a few percent the mass of carbon monoxide, hydrocarbons, carbon dioxide and the number of solid particles.

\section{Tasks and features of glow plugs}

According to [7] glow plugs must provide a high temperature within as short a time as possible to assist with ignition. Such a high temperature should be maintained regardless of the ambient conditions, or eventually adjusted to their variations.

The older diesel engines with antechamber or turbulence chamber injection and direct injection versions with 2-valve arrangement possessed enough space for the placement of injection nozzles and glow plugs. The modern diesel engines with common rail or pump-nozzle injection systems and 4-valve technology required glow plugs with a very thin and long shape due to a very restricted space available for such plugs in combustion chamber. Such problem was reported also in [24], together with the shortage of installation space in the cylinder head. According to [10], Fiat also signaled problems with the installation of the glow plug when developing the $1.3 \mathrm{~L}$ four-cylinder diesel engine with four valves per cylinder due to the very limited available space in the cylinder and head. Also, Denger and Mischker [23] indicated that when modifying the valve head to install electro-hydraulic valve drives, the installation position of the injector and the glow plug should also be considered. Therefore, BERU glow plugs have glow tube diameters below $3 \mathrm{~mm}$ [77].

The glow rod should be situated exactly at the edge of the mixture vortex, still projecting sufficiently deep into the combustion chamber for the accurate introduction of the heat. Its protrusion too far into the combustion chamber is unwanted, due to possible interference with the preparation of the injected fuel and thus of the ignitable fuel-air mixture, resulting in an increase in exhaust gas emissions [7, 30].

Only a system optimized in terms of its injection point, quantity, and mixture composition in conjunction with the correct position and thermal rating of the glow plug can ensure high cold-start performance. Even after the engine has been started, the glow plug may not be 'blown cold' by the increased air movement in the combustion chamber. The glow plug needs to possess a sufficient glowing volume so that heat from it can immediately be brought on into the cold-blown zone [7, 30].

BERU glow plugs allow an environmentally-friendly diesel quick start in 2-5 seconds or even below 2 seconds in conjunction with the Instant Start System (ISS), a reliable start-up to $-30^{\circ} \mathrm{C}$, a steady engine start-u, with up to $40 \%$ less carbon-particulate emissions in the warm-up phase for post-heating glow plugs [7, 30].

Idzior [43] reported that the engine Toyota 2.2 D-4D Cat with the degree of compression pressure equal 15.8 utilized ceramic glow plug members attaining of the temperature $1,175^{\circ} \mathrm{C}$.

According to Idzior [43] a fundamentally main problem of glow plug is delivering of the additional necessary energy to the engine starting. As the glow plug subjected is to the activity of burnt fuel it should possess the high resistance to the high temperature, the high pressure, vibrations, the activity of chemical compounds causing the corrosion, and should quickly reach the proper operating temperature and have high durability. Glow plugs demand besides steerings will regulate the definite time of the production of the voltage. Such system possesses also the indicating lamp which shines under of glowing initial. Lengthening glowing causes that the fuel can bum away to the end, where through the secretion smoky becomes lesser even about $49 \%$. Besides the fuel burns away more evenly and put on weight, what causes arising of the greater energy, and the temperature in the combustion space grows up more quickly, diminishes this the inequality of the work during the start, audible as characteristic for diesel engines „clattering".

According to [7] the glow comprises the plug body, heat rod with mentioned coils, and the connecting bolt. The corrosion-resistant glow rod is pressed in the housing so that as to be gastight. The plug is additionally sealed by a sealing ring or a plastic component at the connector. The electrical energy supplied from the battery is controlled by an electronic glow time control unit.

According to Houben et al. [41] the external cover of glow plug is often made of steel, e.g., Inconel, and is connected to the ground (GND). Inside the cover are the heating resistance $\mathrm{Rh}$ and controlling resistance Rc (Fig. 1), connected in series. The gap between the cover and the resistance is filled with insulation powder. After the power supply, an electric voltage rises between one end of the controlling resistance and the cover, allowing an electric current to flow via the coil. At ambient temperature, the heating resistance is much greater than the controlling one. Therefore, the Rh generates more heat than Rc, enabling the fast rise of the temperature at the tip. The controlling resistance Rc depends on temperature and enhances with temperature rise, thus generating more heat at a higher temperature. This ensures a more evenly distributed temperature along the glow plug.

As explained in [7] during mechanical compaction, the powder is much compressed what makes an entire coil so stable that the thin wires of the heating and regulating coil can permanently resist all vibrations. Even though the individual windings are arranged only a few tenths of a millimeter apart, neither winding short circuits nor short circuits to the glow tube destroying the plug can be produced. With the different materials, lengths and diameters, and different wire thicknesses for the heating and regulating coil, it is possible to change the heat-up times and glow temperatures of the plug in an accordance with the respective requirements of the engine. 
Also, according to [7] during pre-heating, a high current initially flows through the connecting bolt and the regulating coil to the heating coil. The latter heats up quickly, initiating the glow of the heating zone. The glow quickly expands, and after 2-5 seconds, the heating rod glows up to near the plug body. This enhances the temperature of the regulating coil earlier heated up by the current. This increased the electrical resistance reducing the current to a point preventing any damage to the glow rod. After the non-successive engine start, the glow plug is switched off by the glow time control unit after a certain standby time. Under the positive resistance-temperature dependence of the alloy used to glow plugs, the regulating coil can be designed in such a manner that it initially lets via a higher current to the heating coil than when it reaches the target temperature. The latter is thus reached quicker and is maintained within the permissible range by an enhanced regulating effect.

Interestingly, Wlodarczyk [83] described the design and performance of a miniature cylinder pressure sensor packaged as a device integrated with a glow plug.

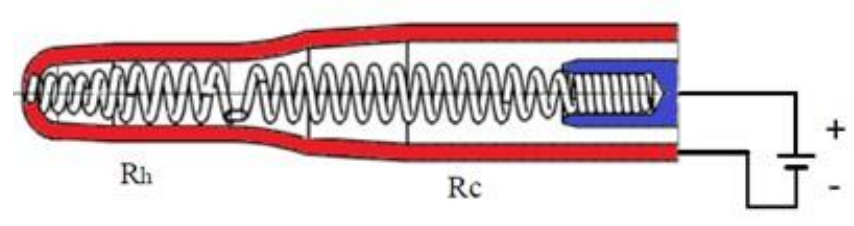

Fig. 1. Glow plug geometry (own elaboration)

\section{Researches on glow plugs applied in CI engines}

There are several numerical and experimental (Table 2) studies on application of glow plugs for CI engines.

Formaggia et al. [28] elaborated a mathematical model of operation of a glow-plug used in Diesel engines to preheat the air-diesel fuel mixture. The model comprises a time-dependent one-dimensional partial differential equation incorporating the electro-thermal interaction between the electric current flowing in the plug and the temperature. They conducted several numerical simulations to assess the validity of the model and compared obtained results with available experimental data.

Suteekarn et al. [80] proposed a robust, real-time, and accurate temperature model to be used with a model-based temperature controller. This allowed an effective control of glow plug surface temperature.

Using the Finite Element Method (FEM) Maassen and Thomas [54] studied the low-cycle fatigue mechanism in relation to the cylinder head with the valve turned $45^{\circ}$ and conventionally flat geometries of the channels. They found that, for such a cylinder head, the maximum surface temperatures reach values of almost $250^{\circ} \mathrm{C}$ between the exhaust valves and in the area of the glow plug. This heterogeneous temperature distribution in combination with the static preloads led to high pressure loads, especially in the area of the combustion chamber roof.

McGhee et al. [57] experimentally studied the effect of fuel injection strategy on cycle-by-cycle stability. They investigated an influence of the number, separation, and quantity of pilot injections on the coefficient of variation of IMEP at $-20^{\circ} \mathrm{C}, 1,000 \mathrm{rev} / \mathrm{min}$, post-start idling conditions.
They also studied an injection strategy and glow plug temperature trade-off at a range of soak temperatures.

Geca et al. [29] studied three power-assisted cold startup systems of the modern diesel engine based on the glow plugs in the combustion chamber and the glow plugs with heating coil and flame glow plugs placed in the intake system. They investigated GAZ Gazelle van fitted with an engine ADCR ANDORIA originally equipped with glow plugs. Engine start-up was performed after a minimum of 8 hours stop at a temperature of the engine of $0^{\circ} \mathrm{C}$. They determined the rate of start-up, a load of the electrical system and toxic exhaust emissions. They found the cold start system with glow plugs with a heating coil as the most overloading the vehicle wiring system. However, it decreased emissions of toxic components. An alternative cold-start system was the one with the flame glow plug. However, its use enhanced by $31 \%$ emissions of unburned hydrocarbons and almost 10 times the value of the instantaneous smoke.

Pan and Wallace [65] numerically studied the ignition of high-pressure natural gas jets in a CI engine with glow plug ignition assist. They elaborated and used a KIVA-3Vbased three-dimensional engine model, along with an improved fuel injector model, a detailed cut-off glow plug shield model and a modified two-step methane reaction mechanism, to map the natural gas injection and ignition. They found that in comparison to an unshielded (bare) glow plug, the shield not only decreased the heat loss from the hot glow plug surface to the cold inlet air charge and the cold injected gas jet but also trapped the fuel mixture to enhance its residence time adjacent to the hot surface. For some heavy-duty diesel engine operating conditions, a shielded glow plug increased the natural gas engine performance and provided reliable ignition, while an unshielded glow plug allowed its optimization for specific conditions. The use of a shield improved the thermal performance of a glow plug, and thereby reduced ignition time. However, the use of a simple shield with only one circular opening can delay flame propagation out of the shield.

Manente et al. [56] studied the effect of inlet temperature and amount of residual gases on the performance of a Mini High Speed Glow Plug Engine.

Yao et al. [87] studied the effects of glow plug assist on a four-cylinder compression ignition (CI) engine fueled with dieseline. They utilized the test engine with pressure sensor glow plugs (PSG) controlled through the elaborated a glow plug control unit (GPCU) with the closed-loop power feedback control algorithm implemented. The was tested at three speeds under varying loads. As a part of multimode combustion for CI engines, glow plug assisted combustion (GA-CI) took place earlier combustion phases and higher peak in-cylinder pressure. GA-CI allowed decreasing cycle-to-cycle variations and prevented misfires, particularly at low load conditions. The glow plug assisting process was based on enhancing the in-cylinder temperature and fuel reactivity. Glow plugs also affected triggering the auto-ignition of the pre-mixture. With glow plug assist, $\mathrm{NO}_{\mathrm{x}}$ emissions increased slightly but were below $0.2 \mathrm{~g} / \mathrm{kWh}$, whereas particulate matter (PM) emissions dropped sharply and weakened to under $0.02 \mathrm{~g} / \mathrm{kWh}$. The presented simulta- 
neously decrease in emissions of $\mathrm{CO}$ and $\mathrm{HC}$ allowed the increase of the combustion efficiency reaching the maximum above $98 \%$.

Li et al. [51] studied factors affecting combustion initiation using a glow plug using a test single-cylinder, common rail diesel engine with a geometric $\mathrm{CR}$ of 15.5 , and a quiescent combustion bomb with optical access. The application of a glow plug prevented engine misfires when the bulk gas temperature at the start of injection was less than $413^{\circ} \mathrm{C}$. The distance between the glow plug and the spray edge, the glow plug temperature, and the bulk gas temperature were important factors affecting two requirements for successful ignition: a minimum local temperature of $413^{\circ} \mathrm{C}$ and a minimum air/fuel vapour equivalence ratio of $0.15-0.35$.

Using an optical constant volume combustion chamber (CCVC) with a pilot plus main injection strategy Pastor et al. [67] studied the development of a fuel spray ignition occurring in a glow-plug assisted engine under simulated low-temperature cold start conditions. They found that pilot ignition occurs in the vicinity of the glow plug, and strongly influences main combustion initiation.

Pischinger et al. [69] investigated the ignition of diesel fuel with a glow plug at low temperatures in a model highpressure combustion chamber and an optical diesel engine. Measurements in the high-pressure chamber showed on the one hand the spread of the jet, and on the other hand, the progress of combustion. Small amounts of fuel converted to soot faster but exhibited a much larger scatter as the flame zone advanced than large amounts of fuel, indicating ignition problems. With the glow plug probe diameters equal to 4.7 and $6.3 \mathrm{~mm}$, respectively, and the corresponding injector inclination angles, there is a position in which the glow plug is injected tangentially with long switching times and hence large amounts of fuel. As a result, a reaction zone is created on the glow plug which usually initiates further combustion as soon as the injection process is completed. It was found that the probability of misfiring increases with increasing distance between the fuel jet and the glow plug and with a smaller protrusion. At a speed of $1000 \mathrm{rpm}$, the onset of combustion correlated with the onset of soot formation in all tested cases. At an engine speed of $500 \mathrm{rpm}$, combustion already occurred during the injection process, before the first visible glow of the soot. It is difficult to determine the location of the reaction zone with the first visible glow of the soot when the plow-wall interaction plays a dominant role at large distances between the surface of the hot glow plug and the edge of the stream. During cold start-up and idling, the directed interaction between the piston cavity and the fuel jet led to an increase in cyclic fluctuations. On the other hand, lower blow-through losses and lower wall heat losses with increasing speed stabilized the combustion process.

BERU AG [52] studied the readiness for starting, starting stability and $\mathrm{HC}$ emissions of a 1.9-liter diesel engine equipped with one steel glow plug and one ceramic plug. The author reported that a diesel engine with ceramic plugs had a cold start behavior comparable to steel glow plugs only when the ceramic plugs reached a temperature of at least $400 \mathrm{~K}$ higher due to their four-fold less thermal mass.

Oehler et al. [64] reported that for the heavy truck series TGX and TGS, MAN has developed a 16-liter V-8 engine with $500 \mathrm{~kW}$ and 3,000 $\mathrm{Nm}$ of torque. It uses an SCR system with AdBlue injection to reduce $\mathrm{NO}_{\mathrm{x}}$. It uses a standard flame ignition system with one glow plug in the manifold in front of the distribution pipes to allow the charge air to preheat in the event of a cold start and low outside temperatures.

During researches on the combustion process of diesel fuel Holzendorf et al. [40] used a standard passenger car diesel engine equipped with an engine control unit with an emulating probe (ETK) and injectors with solenoid valve technology. One cylinder of the tested engine was equipped with a piezoresistive pressure sensor integrated with the glow plug. The signal of such a sensor was read directly from the engine controller using the ETK interface. Injection parameters were also adjusted via the latter.

The engine manufacturer dr. Schrick GmbH [35] developed a small, high-speed diesel engine for small aircraft. It was a $600 \mathrm{cc}$ direct injection two-cylinder diesel engine. BERU glow plugs with optimized filaments were used to start it.

Table 2. The application of glow plugs for CI engines

\begin{tabular}{|l|l|l|c|}
\hline $\begin{array}{l}\text { Configuration/Type } \\
\text { of Glow Plug }\end{array}$ & Engine & $\begin{array}{l}\text { Features/ } \\
\text { Modifications }\end{array}$ & Refs \\
\hline $\begin{array}{l}\text { One glow plug in } \\
\text { a cylinder }\end{array}$ & Single-cylinder HPCR diesel engine with a CR of 15.5:1 & n.a. & {$[57]$} \\
\hline $\begin{array}{l}\text { One glow plug in } \\
\text { each cylinder }\end{array}$ & ADCR Andoria CI engine & n.a. & {$[29]$} \\
\hline $\begin{array}{l}\text { One glow plug in } \\
\text { a cylinder }\end{array}$ & $\begin{array}{l}\text { A model airplane one-cylinder engine with a displacement volume of 4.11 } \\
\mathrm{cm}^{3} \text { and a geometrical CR of 13.91 }\end{array}$ & n.a. & {$[56]$} \\
\hline $\begin{array}{l}\text { Pressure sensor glow } \\
\text { plugs }\end{array}$ & A four-cylinder compression ignition (CI) engine fueled with dieseline & $\begin{array}{l}\text { a glow plug control unit (GPCU) with } \\
\text { the closed-loop power feedback } \\
\text { control algorithm introduced }\end{array}$ & {$[87,56]$} \\
\hline $\begin{array}{l}\text { One glow plug in } \\
\text { cylinder }\end{array}$ & $\begin{array}{l}\text { Test single-cylinder, common rail diesel engine with a geometric CR of } \\
15.5\end{array}$ & n.a. & {$[51]$} \\
\hline $\begin{array}{l}\text { One glow plug in } \\
\text { cylinder }\end{array}$ & Test 1.9-liter diesel engine with one steel glow plug and one ceramic plug & n.a. & {$[52]$} \\
\hline $\begin{array}{l}\text { One glow plug in } \\
\text { cylinder }\end{array}$ & 600cc direct injection two-cylinder diesel engine & $\begin{array}{l}\text { BERU glow plugs with optimized } \\
\text { filaments }\end{array}$ & {$[35]$} \\
\hline $\begin{array}{l}\text { One glow plug in } \\
\text { cylinder }\end{array}$ & $\begin{array}{l}\text { Test single cylinder common rail diesel engine with a piezoresistive pres- } \\
\text { sure sensor integrated with the glow plug }\end{array}$ & n.a. & {$[40]$} \\
\hline
\end{tabular}


It is clearly visible that the effect of the use of glow plugs on the operation of CI engines was investigated numerically using various mathematical models and experimentally using different single- or four-cylinder CI test engines.

\section{The use of glow plugs for gasoline engines}

There are several studies on application of glow plugs for gasoline engines.

Manente et al. [55] applied glow plugs on a model SI engine.

Borgqvist et al. [16] studied the effect of glow plugs on gasoline PPCI combustion, and combustion stability and efficiency were compared with glow plugs turned on or turned off.

Wang et al. [82] tested blended fuels from gasoline and diesel on a CI engine. They reported the possibility of the extension of the low load range of gasoline PPCI using glow plug, but there was no result given or further research.

Zhou et al. [88] proposed the utilization of glow plugs to enhance the combustion stability of partially premixed compression ignition PPCI combustion at idle or low loads, assisting the auto-ignition of gasoline or fuel with high octane number. The low load ignition assist application of glow plug differs significantly from the traditional cold start assist. Additionally, to the simply heating the air in the cylinder, in the PPCI engine the glow plug heats the charge to specific temperatures at a specific time, what is needed to the ignition timing control in PPCI combustion.

It is visible that the effect of the use of glow plugs on the operation of the gasoline engines has rather seldomly been investigated both numerically and experimentally.

\section{The application of glow plugs in natural gas engines, methanol engines and hydrogen engines}

There are several studies on application of glow plugs for direct injected natural gas engines (Table 3).

Aesoy utilized glow plugs to assist compression ignition of natural gas in large-bore turbocharged DI diesel engine for marine applications. Therein only one cylinder was modified for gas operation. A pin-shaped DC glow plug with an internal thermocouple, oriented such that the fuel jet would impinge thereon, was introduced in that cylinder [2-4].

Using the mentioned modified diesel engine and using a constant volume combustion bomb Aesoy and Valland [5] found that surface temperature above $1,200 \mathrm{~K}$ was needed to achieve acceptable ignition affected by natural gas composition and system parameters such as injection and hot surface geometry. They also developed a mathematical model of that tester.

Bartunek and Hilger [12] developed the similar direct injection natural gas system, but predestined for heavy-duty vehicles, and allowing a dethrottled operation at high CRs of 16-18. Such a system comprised a high-pressure injector (up to 300 bar) and a conventional Diesel glow plug as a hot surface. That glow plug was shielded by a cover to limit thermal losses to the in-cylinder charge, as this decreased the necessary electric power and the thermal stress on the glow plug. Perforating the shield ensured contact between the air/fuel mixture and the glow plug over a wide range of operation. Such perforating promoted combustion by increasing the initial reactive volume.

Bartunek et al. [11] studied the effects of shield geometry (number and diameter of bores), auxiliary glow plug power, injection parameters (nozzle number, injection pressure and injection timing), CR and EGR rate on the operation of Diesel engine supplied with natural gas and utilized in city buses. They found that the electric power needed by the glow plug for stable engine operation weakened with load. They also found that the ignition delay depended on the number of injector nozzles and their orientation respective to the glow plug.

Agarwal and Assanis [6] explained that since methane is the least reactive among hydrocarbon fuels, it requires very high ambient temperatures $(1,200-1,300 \mathrm{~K})$ for reasonable ignition delay times, achievable by complex, external ignition systems such as like glow plugs, spark plugs or pilot fuel injection.

Araki et al. [9] found that the components of $\mathrm{C}_{2} \mathrm{H}_{6}$ and $\mathrm{C}_{3} \mathrm{H}_{8}$ in $\mathrm{CNG}$ were important in the auto-ignition process of natural gas. The ignition process of $\mathrm{CNG}$ was assisted by a glow plug, which was set in the cylinder at $30 \mathrm{~mm}$ downstream from the fuel injector nozzle exit.

Scholl [75] found that combustion parameters were not sensitive to the individual glow plug used when CA50 (Crank angle position where $50 \%$ of the heat is released) was the controlled parameter. Electric properties such as HSI resistance and power differed significantly among the glow plug tested due to differences in their resistancetemperature correlation. Such a correlation varied over time. The process of glow plug ageing resulted in an enhancement of the required set resistance for the same HS temperature and was affected by an engine operating time. The degradation process resulted from a gradual loosening of the crimping connection of the inner electric glow plug leading to failure of the glow plug.

Using a Cooperative Fuel Research (CFR) engine Fabbroni and Wallace [26] studied the combustion of natural gas jets under CI engine conditions over a characteristic range of temperatures and pressures, with and without a glow plug shield. They found that the geometry of the injection pattern, combustion chamber, and glow plug shield mostly controlled combustion rates and fuel utilization.

Such authors also reported in [27] that ignition of adjacent gas jets requires a flammable path between jets. It was achievable via mixing between the entrainment regions of adjacent jets and via mixing along the cylinder wall of adjacent jets that are spreading along the wall. Such pathways of ignition allowed high fuel utilization and combustion rates and low combustion variability. No autoignition of an adjacent jet due to heat generation during ignition of the first jet was registered.

Hanenkamp et al. [34] elaborated a turbocharged largebore stationary gas engine operating with a Performance Gas Injection (PGI) system. Despite the same high-pressure fuel injector and glow plug, the PGI system differed from the direct injection system reported in [2]. For the PGI system, the main in-cylinder charge was not stratified but homogeneous. The main combustion chamber was filled 
with highly diluted air-fuel mixture. Both injector and glow plug were built inside a prechamber. The timed pilot injec- tion (230 bar) provided stoichiometric conditions inside the prechamber.

Table 3. The application of glow plugs for engines supplied with a natural gas

\begin{tabular}{|c|c|c|c|}
\hline Configuration/Type of Glow Plug & Engine & Features/Modifications & Refs \\
\hline $\begin{array}{l}\text { A standard } 6 \mathrm{~mm} \text { Bosch pin-shaped } \\
\text { DC glow plug with an internal ther- } \\
\text { mocouple }\end{array}$ & $\begin{array}{l}\text { 4-cylinder, 4-stroke low-speed turbo- } \\
\text { charged Diesel engine with a CR of } \\
12.1: 1 \text { and a displacement volume of } \\
281 / \text { cylinder. }\end{array}$ & $\begin{array}{l}\text { One cylinder was modified for gas operation, where an elec- } \\
\text { tronic injector injects the gaseous fuel directly into the cylin- } \\
\text { der at 200-300 bars at the end of the compression stroke }\end{array}$ & {$[2-5]$} \\
\hline $\begin{array}{l}\text { A conventional Diesel glow plug } \\
\text { shielded by a perforated cover }\end{array}$ & $\begin{array}{l}\text { 4-cylinder, 4-stroke low-speed turbo- } \\
\text { charged diesel engine }\end{array}$ & $\begin{array}{l}\text { The dethrottled operation at high CRs of } 16-18 \text { was achieva- } \\
\text { ble. The system comprised a high-pressure injector (up to } 300 \\
\text { bar) }\end{array}$ & {$[12]$} \\
\hline One glow plug in each cylinder & $\begin{array}{l}12 \mathrm{~L} \text { turbocharged 6-cylinder diesel } \\
\text { engine (OM447 hLA) }\end{array}$ & The system comprised a high-pressure injector of natural gas & [11] \\
\hline $\begin{array}{l}\text { A glow plug in the cylinder set at } 30 \\
\text { mm downstream from the fuel injec- } \\
\text { tor nozzle exit. }\end{array}$ & $\begin{array}{l}\text { A rapid compression machine (RCM) } \\
\text { with the CR of } 10 . \text { The diameter and } \\
\text { thickness of the combustion chamber } \\
\text { were of } 80 \mathrm{~mm} \text { and } 20 \mathrm{~mm}\end{array}$ & $\begin{array}{l}\text { A single hole injector }(7.0 \mathrm{MPa}) \text {. The fuel injection time } 50- \\
60 \mathrm{~ms} \text { from the compression start. Two CNGs tested; } 12 \mathrm{~A} \\
\left(\mathrm{CH}_{4}: 99.1 \%\right) \text { and } 13 \mathrm{~A}\left(\mathrm{CH}_{4}: 86.3 \%, \mathrm{C}_{2} \mathrm{H}_{6}: 5.2 \%, \mathrm{C}_{3} \mathrm{H}_{8}: 1.9 \%\right. \\
\text { and others }) \text {. }\end{array}$ & [9] \\
\hline $\begin{array}{l}\text { Glow plug investigated separately } \\
\text { and than included in numerical model } \\
\text { of engine }\end{array}$ & $\begin{array}{l}\text { Water-cooled horizontal four-stroke } \\
\text { single-cylinder, SenerTec Dachs G5.5 } \\
\mathrm{kW}, \mathrm{CR} \text { (geom.) 13.2:1, Stroke/Bore } \\
91 \mathrm{~mm} / 90 \mathrm{~mm} \text {, Displacement volume } \\
578 \mathrm{~cm}^{3}\end{array}$ & $\begin{array}{l}\text { Crank shaft is connected to a three-phase asynchronous gene- } \\
\text { rator by a single gear step, modified spark plug utilized }\end{array}$ & [75] \\
\hline Shielded glow plug & $\begin{array}{l}\text { A Cooperative Fuel Research (CFR) } \\
\text { engine }\end{array}$ & n.a. & $\begin{array}{l}{[26,} \\
27]\end{array}$ \\
\hline $\begin{array}{l}\text { A standard } 6 \mathrm{~mm} \text { Bosch pin-shaped } \\
\text { DC glow plug with an internal ther- } \\
\text { mocouple }\end{array}$ & $\begin{array}{l}\text { MAN Diesel 32/40, 12-cylinder, } 32 \\
\text { 1/cylinder }\end{array}$ & A Performance Gas Injection (PGI) system introduced & $\begin{array}{l}34], \\
{[70]}\end{array}$ \\
\hline $\begin{array}{l}\text { A resistive heating coil installed on } \\
\text { the upper part of the prechamber, } \\
\text { dissipating a maximum of } 195 \mathrm{~W} \text { of } \\
\text { heating power. }\end{array}$ & $\begin{array}{l}\text { Single cylinder } 2 \text { valves test engine } \\
(\mathrm{CR}=8.5-14, \lambda=1-1.6, \mathrm{RPM}= \\
1150 / 1500 \mathrm{~min}^{-1}\end{array}$ & $\begin{array}{l}\text { Three access ports in a cylinder. The spark plug is mounted in } \\
\text { the first lateral port. The prechamber with a volume of } 1630 \\
\mathrm{~mm}^{3} \text { and cylindrical-conical shape was placed in the central } \\
\text { port and the pressure sensor was installed in the second lateral } \\
\text { port. }\end{array}$ & {$[38]$} \\
\hline One glow plug introduced & $\begin{array}{l}\text { Single-cylinder four-cycle DI diesel } \\
\text { engine with a high-swirled deep-bowl } \\
\text { combustion chamber }\end{array}$ & n.a. & $\begin{array}{l}{[44,} \\
27]\end{array}$ \\
\hline One glow plug in each cylinder & $\begin{array}{l}\text { Single-cylinder engine charged by the } \\
\text { natural gas/air mixture with an equiva- } \\
\text { lence ratio of } 0.6\end{array}$ & n.a. & $\begin{array}{c}{[86,} \\
55]\end{array}$ \\
\hline
\end{tabular}

Using the similar CI engine with the PGI system Prager [70] studied the effect of injection timing, load, and relative air-fuel ratio on combustion and emission characteristics of the engine. Injection timing was adjustable in a narrow range of max $6^{\circ} \mathrm{CA}$. At medium load of $11 \mathrm{bar}$, this enabled the engine to operate in a combustion phasing range of approximately $15^{\circ} \mathrm{CA}$, though combustion duration was gradually increased with retarded CA50 due to falling levels of turbulence in the combustion chamber.

Wunsch et al. [85] and Heyne et al. [38] numerically and experimentally studied an ignition concept based on autoignition of air-fuel mixtures in a heated unscavenged prechamber for medium-sized natural gas cogeneration applications. Prechamber temperature was controlled by resistive heating and allowed adjusting the timing of the autoignition event within a certain range. The narrow system's operating range allowed for stable engine operation at over-advanced combustion phasings, advertising the engine efficiency and $\mathrm{NO}_{\mathrm{x}}$ emission. The lean-burn quality of the engine decreased due to high cyclic variations at the start of combustion.

Using a glow-plug assisted direct-injection Diesel engine Ikegami et al. [44] studied effects of engine parameters on thermal efficiency, smoke, oxides of nitrogen, and unburned hydrocarbons for butane, methanol, and pure aro- matic fuel. The less noisy and smoky operation were achieved under certain CRs and injection timings not obtainable with ordinary Diesel engines. Such characteristic was caused by a two-staged combustion: a lower rate of heat release in the earlier burning stage and a higher rate in the later stages.

Habbaky [33] studied an inducing the combustion of natural gas in the bomb via a glow plug.

According to Cheng and Wallace [21] glow plugs can be an ignition source for direct-injected natural gas engines. In the cycle-by-cycle ignition assist application, the glow plugs achieve high surface temperatures at specific times in the engine cycle to provide a localized source of ignition. The thickness of the heat penetration layer is small within the time scale of the ignition preparation period (1-2 ms). They developed a simplified heat transfer model considering both convection and radiation losses, for computing the heat transfer to and from the surrounding gas. They also elaborated a scheme for coupling the glow plug model to the surrounding gas computational domain in KIVA-3V was also developed. The glow plug model allowed proper simulation of the natural gas ignition process for a direct injection natural gas engine. It also provided detailed information on the local glow plug surface temperature distribution $(\%)$. 
Abate [1] obtained a linear dependency between the electrical resistance and the steady-state glow plug core temperature.

Pan et al. [66] studied the effect of multi-opening shield designs on natural gas ignition characteristics in glow plugassisted CI engines. Two types of multi-opening glow plug shield with four small circular openings distributed in either diamond-pattern or square-pattern arrangements, were elaborated. They found that both multi-opening shields increased glow plug surface temperature, and the residence time of fuel mixture adjacent to the glow plug surface in the early injection stage, allowing a faster ignition than in case of the single-opening shield. The diamond-pattern multiopening glow plug shield allowed a faster or comparable flame propagation path back to combustion chamber, compared to single-opening shield, while the square-pattern multi-opening one delayed the flame propagation under several specific engine conditions. In comparison to the single-opening glow plug shield, the overall natural gas ignition delays further decreased by $6-44 \%$ in case of the diamond-pattern multi-opening shield, while the squarepattern multi-opening one decreased such a delay only for a few specific conditions.

Yamaya et al. [86] studied a glow-plug assisted procedure allowing an easy start and warm-up processes of the premixed-compression-ignition (i.e., homogeneous charge compression ignition, HCCI) natural-gas engines easy. They conducted an experiment on a single-cylinder engine charged by the natural gas/air mixture with an equivalence ratio of 0.6. The wall temperature of the combustion chamber controlled the heat release of hot-flame explosion for the engine starting and warming, even though the glow plug could assist the ignition process of the mixture. Reaching the blue-flame dominant charge temperature equal to $850 \mathrm{~K}$, near the top dead center during the compression stroke was needed to establish self-sustaining engine operations. A glow plug installation raised the local mixture temperature resulting in the higher local temperature of the compressed mixture. The formaldehyde addition into the charge facilitated reaching the hot-flame ignition during the starting and warming.

There are several studies on application of glow plugs for direct injected methanol engines (Table 4).

Kroeger [50] reported that the methanol engine with glow plugs had thermal efficiency close to that of the diesel engine from which it was derived. Additionally, nitrogen oxide emissions decreased by 50 percent and exhaust smoke was negligible. However, Hydrocarbon emissions were above the baseline diesel engine.

Using the Detroit Diesel Corporation (DDC) two-cycle, DI, CI engine, Goering et al. [31] evaluated performance and durability effects of anhydrous and hydrated ethanol. A catalytic converter installed effectively weakened HC and $\mathrm{CO}$ emissions from the engine. The water in the hydrated ethanol allowed decreasing $\mathrm{NO}_{\mathrm{x}}, \mathrm{HC}$, and $\mathrm{CO}$ emissions.

Havenith et al. [37] found that in the whole operational range the methanol engine with glow plugs exhibited an energy consumption close to its diesel counterpart, together with a low emission.
Neame and Wallace [60] studied extending the range of operation of a particular glow plug/fuel injection nozzle geometry by placing the glow plug in the wake of a bluff body. They found that addition of the bluff body weakened the $\mathrm{NO}_{\mathrm{x}}$ emissions of the methanol fueled engine at a small penalty in fuel consumption and enhanced $\mathrm{CO}$ and unburned hydrocarbon emissions.

Using the 4-stroke heavy-duty DI diesel engine Mueller and Musculus [59] compared the glow-plug-assisted ignition and combustion of pure methanol (M100) with that of a two-component paraffinic diesel reference fuel with a cetane number of $45(\mathrm{CN} 45)$. They reported that $\mathrm{CN} 45$ readily auto-ignited at the conditions studied, contrary to M100. The glow-plug-assisted ignition of M100 was affected by glow plug (GP) temperature and proximity to a fuel jet.

Ambekar et al. [8] reported the use of glow plugs assisting for spray combustion of liquid nitromethane in air within a constant volume chamber.

According to [19], using the water and oxygen generated during high-pressure electrolysis, WissenschaftlichTechnische Zentrum (WTZ) Roßlau has developed a zeroemission engine cycle. It uses a combustion process of hydrogen associated with the operation of glow plugs like the combustion of diesel fuel. The tests for the selected engine concept were carried out on a single-cylinder research engine with a bore diameter of $128 \mathrm{~mm}$ and a compression ratio of 15.5 . The combustion was carried out in the combustion process conditioned by the operation of glow plugs required as an ignition source supporting the initiation of hydrogen self-ignition.

Table 4. The application of glow plugs for engines supplied with methanol

\begin{tabular}{|c|c|c|c|}
\hline $\begin{array}{l}\text { Configuration/Type } \\
\text { of glow plug }\end{array}$ & Engine & $\begin{array}{l}\text { Features/ } \\
\text { Modifications }\end{array}$ & Refs \\
\hline $\begin{array}{l}\text { One glow plug in } \\
\text { each cylinder }\end{array}$ & $\begin{array}{l}\text { Modified Caterpilar } \\
\text { CI engine }\end{array}$ & $\begin{array}{l}\text { Injection system of } \\
\text { greater capacity } \\
\text { than original one } \\
\text { was introduced for } \\
\text { methanol }\end{array}$ & [50] \\
\hline $\begin{array}{l}\text { One glow plug in } \\
\text { each cylinder used } \\
\text { at start-up, warm- } \\
\text { up and low engine } \\
\text { speeds and loads }\end{array}$ & $\begin{array}{l}\text { Detroit Diesel Di, } \\
\text { CI V6 two-cycle } \\
\text { buss engine }\end{array}$ & $\begin{array}{l}\text { Modified injection } \\
\text { system for ethanol } \\
\text { and a catalytic } \\
\text { converter were } \\
\text { introduced }\end{array}$ & [31] \\
\hline $\begin{array}{l}\text { One glow plug in } \\
\text { each cylinder }\end{array}$ & $\begin{array}{l}\text { Modified air- } \\
\text { cooled, V8 diesel } \\
\text { engine F8L 413F, } \\
\text { with a high swirl } \\
\text { direct injection } \\
\text { combustion system }\end{array}$ & $\begin{array}{l}\text { Modified injection } \\
\text { system for methanol } \\
\text { was introduced }\end{array}$ & [37] \\
\hline $\begin{array}{l}\text { Four different glow } \\
\text { plug/fuel injection } \\
\text { nozzle geometries } \\
\text { with and without a } \\
\text { bluff-body stabi- } \\
\text { lizer studied }\end{array}$ & $\begin{array}{l}\text { Single-cylinder } \\
\text { CFR cetane rating } \\
\text { engine fueled with } \\
\text { methanol }\end{array}$ & n.a. & {$[60]$} \\
\hline $\begin{array}{l}\text { One glow plug in } \\
\text { each cylinder }\end{array}$ & $\begin{array}{l}\text { 4-stroke, heavy- } \\
\text { duty DI diesel } \\
\text { engine }\end{array}$ & $\begin{array}{l}\text { Engine modified to } \\
\text { provide extensive } \\
\text { optical access into } \\
\text { the combustion } \\
\text { chamber. }\end{array}$ & [59] \\
\hline
\end{tabular}


It is clearly visible that the effect of application of various glow plugs on the operation of engines supplied with natural gas has often been investigated both numerically and experimentally. The much rarely has been studied the influence of the application of glow plugs on behavior of engines supplied with methanol.

\section{Failures of glow plugs}

\subsection{Bad glow plug symptoms}

According to Stevens [79] bad glow plug symptoms include:

\section{1 - Difficulty Starting the Vehicle}

A CI engine cannot usually start with bad glow plugs as they do not generate enough heat to warm the cylinder and ignite the fuel. It usually takes several attempts to get the vehicle started. The nearly dead glow plugs and freezing outside temperatures prevent the vehicle start at all.

\section{2 - Poor Acceleration}

Even, if possible, to start a diesel engine with a bad glow plug, such an engine cannot perform optimally. You will notice the first sign of reduced performance is noticed when pushing the accelerator results in no generating much speed.

Poor acceleration can happen due to other engine problems, too.

If any of these other bad glow plug symptoms occur alongside poor acceleration, the culprit is likely one or more of engine glow plugs.

\section{3 - Misfiring}

A backfiring exhaust occurs when fuel fails to ignite as it should within the cylinder. Since the glow plugs play an important crucial role in igniting fuel, a misfire in a diesel engine may be affected by problems with glow plugs.

Table 5. The glow plugs related diagnostic trouble codes [63]

\begin{tabular}{|c|c|c|c|}
\hline Code & Description & Severity \& Symptoms & Causes \\
\hline P0380 & $\begin{array}{l}\text { Glow Plug/Heater } \\
\text { Circuit "A". } \\
\text { GM: Glow Plug Per- } \\
\text { formance Conditions }\end{array}$ & \multirow[t]{2}{*}{$\begin{array}{l}\text { - Malfunction Indicator Lamp (MIL) illumination. } \\
\text { - Glow plug/Wait to Start indicator stays illuminated } \\
\text { longer than normal (may be on solid). } \\
\text { - Hard to start condition especially in colder weather. }\end{array}$} & \multirow{2}{*}{$\begin{array}{l}\text { - Fault in glow plug wiring (open, short to ground, etc.). } \\
\text { - Glow plug faulty. } \\
\text { - Open fuse. } \\
\text { - Faulty glow plug relay } \\
\text { - Faulty glow plug module. }\end{array}$} \\
\hline P0382 & $\begin{array}{l}\text { Glow plug/heater } \\
\text { circuit B }\end{array}$ & & \\
\hline \multirow[t]{2}{*}{ P0381 } & $\begin{array}{l}\text { Glow Plug/Heater } \\
\text { Indicator Circuit } \\
\text { Malfunction }\end{array}$ & $\begin{array}{l}\text { - Delayed engine start up, especially during periods of } \\
\text { extremely cold weather. } \\
\text { - Excessive smoke from the exhaust. } \\
\text { - No glow plug indicator illumination. } \\
\text { - Constant glow plug indicator illumination. }\end{array}$ & $\begin{array}{l}\text { - Defective glow plug indicator lamp bulb. } \\
\text { - Faulty glow plug/heater relay. } \\
\text { - Glow plug/heater controller malfunction. } \\
\text { - Open or shorted glow plug/heater indicator circuit. } \\
\text { - Bad instrument panel circuit board. }\end{array}$ \\
\hline & & $\begin{array}{l}\text { - Malfunction Indicator Lamp (MIL) illumination. } \\
\text { - Glow plug / Wait to Start indicator stays illuminated } \\
\text { longer than normal (may be on solid). } \\
\text { - Hard to start condition especially in colder weather. }\end{array}$ & $\begin{array}{l}\text { - Fault in glow plug wiring (open, short to ground, etc.). } \\
\text { - Glow plug faulty. } \\
\text { - Open fuse. } \\
\text { - Faulty glow plug relay. } \\
\text { - Faulty glow plug module. }\end{array}$ \\
\hline P0383 & $\begin{array}{l}\text { Glow Plug Control } \\
\text { Module Circuit Low }\end{array}$ & \multirow{3}{*}{$\begin{array}{l}\text { - The glow plug warning light illuminates, and the engine } \\
\text { is slow to start in warm weather or fail to start in cold } \\
\text { weather. } \\
\text { - If the engine starts, there is a pronounced knocking noise } \\
\text { until the engine warms up to operating temperature. } \\
\text { White smoke is visible from the exhaust as the excess } \\
\text { fuel from the hard start burns off. } \\
\text { - The engine has miss until the cylinder head temperatures } \\
\text { rise sufficiently to support complete combustion. }\end{array}$} & \multirow{3}{*}{$\begin{array}{l}\text { - The glow plugs' life expectancy is of 30,000-40,000 } \\
\text { miles and they have reached their useful life and need } \\
\text { replacement. } \\
\text { - Poor injection timing causes undue wear on the glow } \\
\text { plug. } \\
\text { - Next to the time replacement, a stuck glow plug relay } \\
\text { or timer module burns them very fast. }\end{array}$} \\
\hline P0384 & $\begin{array}{l}\text { Glow Plug Control } \\
\text { Module Circuit High }\end{array}$ & & \\
\hline P0670 & $\begin{array}{l}\text { Glow Plug Control } \\
\text { Module Circuit Fault }\end{array}$ & & \\
\hline P0671 & $\begin{array}{l}\text { Cylinder \#1 Glow Plug } \\
\text { Circuit }\end{array}$ & \multirow{3}{*}{$\begin{array}{l}\text { - The engine management computer (PCM) will set the } \\
\text { code P0671/.../12. The engine will be hard to start or } \\
\text { may not start at all in cold weather or when it has been } \\
\text { sitting long enough for the block to cool. } \\
\text { - Lack of power until the engine heats up sufficiently. } \\
\text { - Engine may miss due to the colder than normal cylinder } \\
\text { head temperature. } \\
\text { - Engine may hesitate when accelerating. No pre-heat } \\
\text { period, or the preheat light does not go off. }\end{array}$} & \multirow{3}{*}{$\begin{array}{l}\text { - Faulty cylinder } \# 1 / \ldots / 12 \text { glow plug. } \\
\text { - Open or shorted glow plug circuit. Damaged wiring } \\
\text { connector. } \\
\text { - Faulty glow plug control module. }\end{array}$} \\
\hline$\cdots$ & $\cdots$ & & \\
\hline P0682 & $\begin{array}{l}\text { Cylinder \#12 Glow } \\
\text { Plug Circuit }\end{array}$ & & \\
\hline P0683 & $\begin{array}{l}\text { Glow Plug Control } \\
\text { Module to PCM } \\
\text { Communication Cir- } \\
\text { cuit }\end{array}$ & \multirow{2}{*}{$\begin{array}{l}\text { - The check engine light will be illuminated, and the } \\
\text { above codes will be set. } \\
\text { - Little if any indication will be present if only one or two } \\
\text { glow plugs have failed. } \\
\text { - If the engine is very cold, it may be a little harder to } \\
\text { start. } \\
\text { - The engine may exhibit a miss until it has sufficiently } \\
\text { warmed up. } \\
\text { - If more than two glow plugs are malfunctioning, the } \\
\text { engine will be very difficult to start. }\end{array}$} & \multirow{2}{*}{$\begin{array}{l}\text { - Open or short in the wiring from the PCM (powertrain } \\
\text { control module) to the GPCM (glow plug control mod- } \\
\text { ule), to the bus bar, or from the bus bar to the glow } \\
\text { plug. } \\
\text { - Failed glow plug. } \\
\text { - Loose or corroded connections. } \\
\text { - Failed GPCM. } \\
\text { - Loose or corroded connections on the glow plug sole- } \\
\text { noid. } \\
\text { - Glow plug solenoid failure. } \\
\text { - Insufficient battery power to solenoid. } \\
\text { - Code P0670 may accompany this code. This code } \\
\text { points to the wiring harness from the GPCM to the } \\
\text { solenoid as a problem. }\end{array}$} \\
\hline P0684 & $\begin{array}{l}\text { Glow Plug Control } \\
\text { Module to PCM } \\
\text { Communication Cir- } \\
\text { cuit } \\
\text { Range/Performance }\end{array}$ & & \\
\hline
\end{tabular}




\section{4 - Dark Exhaust Smoke}

Several factors can lead to dark gray or black exhaust smoke. If the fault lies with the combustion process, it may result from problems with the glow plugs.

The dark smoke when accelerating is more common in diesel engines but if this symptom occurs with others on this list, a faulty glow plug is suspected.

\section{5 - Disturbing signals from the Checking Engine Lights}

Faulty glow plugs trigger the check engine light and when scanned with an OBD scanner, a glow-plug related error code occurs [63], as shown in Table 5.

It is clearly visible that an increase of cylinder numbers in an engine results in a more complex and expanded diagnostic system of glow plugs set.

\subsection{Low-quality glow plugs}

According to [7], some manufacturers use cheap designs for various glow plugs resulted in the poor quality of the latters. The symptoms of low-quality glow plugs and risks related to them were presented in Table 6 [7].

\subsection{Failures in pencil type glow plugs}

Causes of failure in pencil type glow plugs described in $[7,45,71]$ are presented in Table 7 . It is clearly seen that caused of glow plug failures can be of mechanical, electrical/thermal, and even chemical nature.

The glow plug failure may be due to the damage to the power connection part caused by corrosion. This case is shown in the Fig. 2 for the glow plug used in the 2009 Opel Movano 2.5 CDTI engine.

A glow plug failure may also result from a melting of its heating part. This case for the BERU 0100226384 glow plug used in the 2008 Ford Focus 1.8 tdci engine is presented in Fig. 3.
A glow plug failure due to a melting heater element resulted from the thermal overload for the glow plug used in the 2009 Opel Movano 2.5 CDTI engine is shown in Fig. 4.

Another glow plug failure due to overheating for the NGK Y508J 11V glow plug used in the 2007 IA Sorento 2.5 CRDI engine is presented in Fig. 5.

A glow plug failure due to a broken thread on the power connection end in relation to the Bosch 0250203018 glow plug used in the 2013 Peugeot Boxer 2.2 HDI engine is shown Fig. 6.

It can be noticed that the glow plug failures are often caused by the overheating.

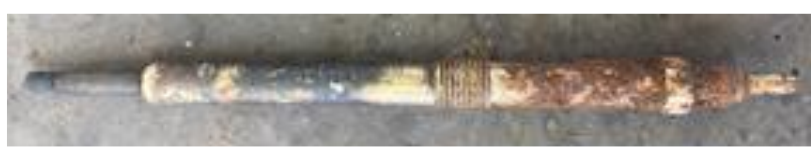

Fig. 2. The glow plug failure due to the damage to the power connection part caused by corrosion for the glow plug used in the 2009 Opel Movano 2.5 CDTI engine. Source: own elaboration

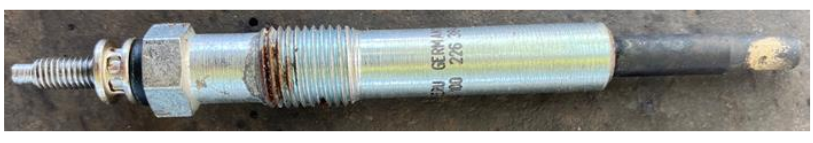

Fig. 3. The glow plug failure resulted from a melting of its heating part for the glow plug used in the 2008 Ford Focus 1.8 tdci engine. Source: own elaboration

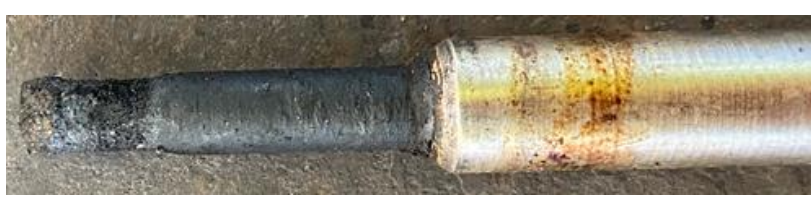

Fig. 4. A glow plug failure due to a melting heater element resulted from the thermal overload for the glow plug used in the 2009 Opel Movano 2.5 CDTI engine. Source: own elaboration

Table 6. The symptoms and risks of low-quality glow plugs

\begin{tabular}{|c|c|}
\hline Symptoms & Risks \\
\hline Single sealing & Not waterproof \\
\hline Filling the glow tube with low grade $\mathrm{Mg}$ powder & Bad insulation, swelling of the glow tube \\
\hline $\begin{array}{l}\text { The only one coil installed instead of the 2-coil technology } \\
\text { required }\end{array}$ & Profile of characteristics not in accordance with the manufacturer's specification \\
\hline Wall thickness not continuous & Glow plug blowing \\
\hline Coil in an inclined position in the glow tube & Short circuit \\
\hline $\begin{array}{l}\text { Glow tube not centered, causing the inclined position of the } \\
\text { glow plug in the antechamber or turbulence one }\end{array}$ & The glow plug destroyed by the injection jet and burns \\
\hline Heating rod with hairline cracks & Glow plug blowing \\
\hline $\begin{array}{l}\text { Heating rod tip is filled with not compressed and/or moist } \\
\text { magnesium powder }\end{array}$ & Short circuit, inflation of the glow rod, weakened service life \\
\hline Round end drilled on, not correctly welded through & Glow plug blowing \\
\hline $\begin{array}{l}\text { Glow tube tip twisted off, } \\
\text { heating rod too thin }\end{array}$ & Scale deposits, weakened service life \\
\hline Glow spiral not properly designed & $\begin{array}{l}\text { Battery overload due to excessive current consumption, increasing the risk of } \\
\text { burning of the glow time control unit } \\
\text { contacts. This weakened the service life or impaired the function }\end{array}$ \\
\hline Glow coil mounted in inclined position & Short circuit \\
\hline Cone incorrectly fitted for the cylinder head & Sealing problems, destruction of the cylinder head \\
\hline Surface without coating & Seizing in the bore \\
\hline Sleeve being only pushed & Loosening and interruption of current supply, loose contact \\
\hline Pencil length not according to manufacturer 's specifications & $\begin{array}{l}\text { Too long pencil length facilitated destruction of glow plug by the injection jet. Too } \\
\text { short one caused start problems }\end{array}$ \\
\hline
\end{tabular}


Table 7. Causes of failure in pencil type glow plugs

\begin{tabular}{|c|c|c|}
\hline Failure symptom & Causes & Refs \\
\hline $\begin{array}{l}\text { Heating rod with folds and } \\
\text { dents }\end{array}$ & $\begin{array}{l}\text { Coil interruption due to: } \\
\text { a) operation at too high voltage, e.g., jump start, } \\
\text { b) too long power supply due to a stuck relay, } \\
\text { c) impermissible post-heating when engine is running, } \\
\text { d) use of a non post-heating glow plug. } \\
\text { Glow plug with no post-glow capability fitted. } \\
\text { Increased alternator voltage. }\end{array}$ & {$[7,71]$} \\
\hline $\begin{array}{l}\text { Heating rod partially or fully } \\
\text { molten or broken off }\end{array}$ & $\begin{array}{l}\text { Overheating of the heating rod due to: } \\
\text { a) beginning of atomization too early, } \\
\text { b) coked or worn nozzles, } \\
\text { c) engine failure, e.g., because of piston jamming, valve breakage, etc., } \\
\text { d) dripping nozzles, } \\
\text { e) seized piston ring. }\end{array}$ & [7] \\
\hline Heating rod top damaged & $\begin{array}{l}\text { Overheating of the heating rod due to: } \\
\text { a) too early atomization initializing an accompanying overheating of heating rod and heating coil causing } \\
\text { brittleness and breaks of the latter, } \\
\text { b) closed annular gap between plug housing and heating rod causing too much heat deflected from the } \\
\text { heating rod, the regulating. }\end{array}$ & {$[7,71]$} \\
\hline $\begin{array}{l}\text { Connecting bolt torn off, } \\
\text { hexagon damaged }\end{array}$ & $\begin{array}{l}\text { a) Torn off connecting bolt resulting from the tightening the current connecting nut with excessive torque. } \\
\text { b) Damaged hexagon resulted from the use of incorrect tool; the plug deformed and causing a short circuit } \\
\text { from the housing to the round nut. }\end{array}$ & [7] \\
\hline No glow-plug continuity & $\begin{array}{l}\text { a) Annular orifice between plug shell and heating element constricted or blocked by coke deposits. } \\
\text { b) Too much heat dissipated by heating element, control coil remains cold and allows too much current to } \\
\text { reach heating coil. }\end{array}$ & [71] \\
\hline Heating element ruptured & $\begin{array}{l}\text { Cheap glow plugs/imitations (tube) may swell, burst, or even explode due to incorrect filling or poor } \\
\text { drying of insulating powder before filling) }\end{array}$ & [71] \\
\hline $\begin{array}{l}\text { Ceramic heating element } \\
\text { melted }\end{array}$ & $\begin{array}{l}\text { a) Installation of wrong glow plug (e. g. } 12 \mathrm{~V} \text { glow plug instead of } 24 \mathrm{~V} \text { glow plug). } \\
\text { b) Defective control unit generating too much voltage or not shutting off current flow soon enough }\end{array}$ & [71] \\
\hline $\begin{array}{l}\text { Ceramic heating element } \\
\text { broken }\end{array}$ & $\begin{array}{l}\text { Incorrect injection point. Incorrect spray pattern. Overvoltage (refer to heating element melted). Incor- } \\
\text { rect fitting due to plug being tilted during installation. }\end{array}$ & [71] \\
\hline Enlarged probe tip & $\begin{array}{l}\text { a) Excessive voltage ( } 12 \mathrm{~V} \text { Glow Plug in the } 24 \mathrm{~V} \text { system or vice versa). } \\
\text { b) Failure of alternator and regulator. } \\
\text { c) Dampness during storage. }\end{array}$ & {$[45]$} \\
\hline Damaged probe tip & $\begin{array}{l}\text { a) Excessive gloving/voltage ( } 24 \text { V Glow Plug in a } 12 \text { V system and vice versa. } \\
\text { b) Failure of alternator and regulator. }\end{array}$ & [45] \\
\hline Damaged or missed probe tip & $\begin{array}{l}\text { a) Failure of ignition unit. } \\
\text { b) Direction or regularity of fuel jet incorrect. } \\
\text { c) Sealing fault causing spraying position error. }\end{array}$ & [45] \\
\hline $\begin{array}{l}\text { Deformed probe due to } \\
\text { overheating }\end{array}$ & $\begin{array}{l}\text { a) Failure of ignition unit. } \\
\text { b) Direction or regularity of fuel jet incorrect. } \\
\text { c) Wrong spraying position due to faulty sealing. } \\
\text { d) Excessive gloving/voltage ( } 24 \text { V Glow Plug in a } 12 \mathrm{~V} \text { system and vice versa). } \\
\text { e) Failure of alternator and regulator. } \\
\text { f) Function or timing fault in injection unit. }\end{array}$ & [45] \\
\hline Swollen ring on the probe tip & Oil in combustion chamber, probably due to engine wear & [45] \\
\hline Missing probe & $\begin{array}{l}\text { a) Ignition unit failure. } \\
\text { b) Direction or regularity of fuel jet incorrect. } \\
\text { c) Wrong spraying position due to faulty sealing. } \\
\text { d) Thread damaged to opening of cylinder head. } \\
\text { e) Glow plug insufficiently tightened causing plug to sit incorrectly. }\end{array}$ & [45] \\
\hline $\begin{array}{l}\text { Probe touching body of glow } \\
\text { plug }\end{array}$ & $\begin{array}{l}\text { a) Over-tightened torque. } \\
\text { b) Wrong tool used. } \\
\text { c) Threat damage to opening of cylinder head. }\end{array}$ & [45] \\
\hline $\begin{array}{l}\text { Holes in probe/ cracks/ } \\
\text { melting next to body of glow } \\
\text { plug }\end{array}$ & $\begin{array}{l}\text { a) Failure of ignition unit. } \\
\text { b) Direction or regularity of fuel jet incorrect. } \\
\text { c) Wrong spraying position due to faulty sealing. } \\
\text { d) Function or timing fault in injection unit. } \\
\text { e) Thread damaged to opening of cylinder head. } \\
\text { f) Glow plug insufficiently tightened causing plug to sit incorrectly. }\end{array}$ & [45] \\
\hline $\begin{array}{l}\text { Carbon deposits between } \\
\text { probe and body of glow plug }\end{array}$ & $\begin{array}{l}\text { a) Failure of ignition unit. } \\
\text { b) Direction or regularity of fuel jet incorrect. } \\
\text { c) Wrong spraying position due to faulty sealing. } \\
\text { d) Injection pump operation/timing failure. }\end{array}$ & [45] \\
\hline Broken/bent power terminal & $\begin{array}{l}\text { a) Over-tightened torque. } \\
\text { b) Wrong tool used. } \\
\text { c) Thread damaged to opening of cylinder head. }\end{array}$ & {$[45]$} \\
\hline
\end{tabular}




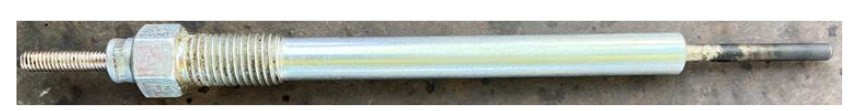

Fig. 5. A glow plug failure due to overheating for the NGK Y508J 11V glow plug used in the 2007 IA Sorento 2.5 CRDI engine. Source: own elaboration

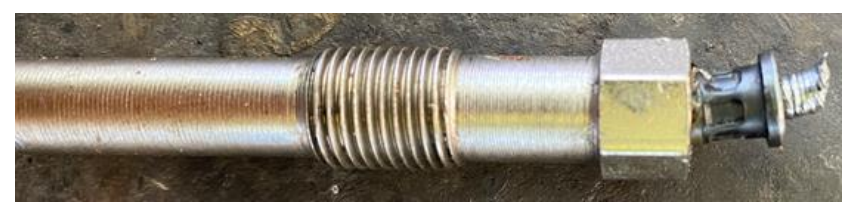

Fig. 6. A glow plug failure due to a broken thread on the power connection end in relation to the glow plug used in the 2013 Peugeot Boxer 2.2 HDI engine. Source: own elaboration

\section{Risks of drive with a bad glow plug}

Over time, glow plugs wear out and negatively affect the CI engine performance. One may continue to start and still drive it, but not as efficiently as when with properly operating glow plugs.

As the glow plugs become weaker, starting the engine take multiple tries, and reaching higher speeds require flooring the gas pedal. In colder regions, the vehicle will not start at all since the glow plugs cannot generate enough heat to trigger combustion.

The improper functioning of the glow plug can cause misfires during ignition.

The driving with the weakened glow plugs is also unwanted, as it weakens their ability to decrease the amount of smoke admitted into the air during engine start-up. The decrease of the mentioned amount of smoke is due to despite though shutting off the light indicator after start-up the glow plugs continue to cycle 3 to 5 minutes after the engine runs. This helps to limit the amount of start-up emissions and the build-up of soot that is usually trapped in the regeneration filter (DPF). The modern diesel engines also comprise a pressure transducer called a glow combustion sensor (GCS). Through measuring the pressure inside the combustion chamber, it serves as an input to the engine control module or computer allowing adjusting air and fuel ratio for optimal running conditions. The improper operation of GCS can result in the weakening of engine operational conditions.

\section{Failure of exemplary glow plug}

The technology of glow plugs with the integrated sensors measuring the pressure in combustion chamber appeared with the development of Euro 6 emission standards. This type of glow plugs can be found, among others in some Opel 2.0 CDTI and VW 2.0 TDI engines manufactured from approx. 2008.

A piezoelectric pressure sensor is located on the top of the glow plug and sends a pressure signal to the engine control unit to optimize combustion and reduce nitrogen oxide emissions.

The characteristic parameters related to the operation of such a glow plug are given in Table 8 .
Table 8 . The characteristic parameters related to the operation of a glow plug applied in the Opel Insignia 2014 2.0 CDTi engine

\begin{tabular}{|l|c|c|}
\hline Parameter & Unit & Value \\
\hline Supply voltage & $\mathrm{V}$ & 5.4 \\
\hline Warm-up time & $\mathrm{s}$ & 2.5 \\
\hline Temperature & ${ }^{\circ} \mathrm{C}$ & 1250 \\
\hline
\end{tabular}

Glow plug technology with an integrated sensor measures the pressure in the combustion chamber and transmits this information to the engine control module, playing a pivotal role in drastically reducing emissions from the CI engine. It is a technology that ensures very good ecological effects of diesel engines.

As an exemplary case for the failure of glow plugs the one related to the relatively quick damage of three glow plugs from the Opel Insignia 2014 2.0 CDTi engine was considered. The components of the one of such glow plugs [13] were presented in Fig. 7.

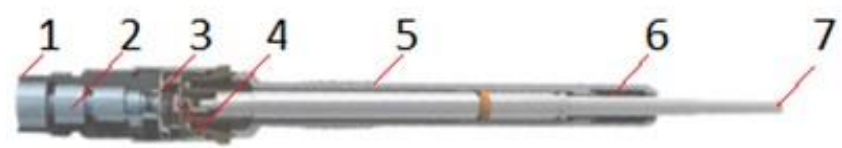

Fig. 7. The components of the glow plug from the Opel Insignia 20142.0 CDTi engine. Source: own elaboration. 1 - caulked nut, 2 - high voltage connection, 3 - printed circuit board with electronic circuit, 4 - measuring diaphragm, 5 - glow plug body, 6 - gasket, 7 - heater tube

During operation of the mentioned diesel engine, the printed circuit board with electronic circuit 3 and the measuring diaphragm 4 were broken. The symptoms of glow plugs' failures were difficulties with the morning engine start in conditions of reduced temperature and increased humidity due to dew deposited on, among others, the glow plug bodies.

Figure 8a showed that whole failed glow plug. Figure $8 \mathrm{~b}$ presented heater tube of the glow plug covered with carbon deposits. The view of the caulked nut is visible in Fig. 8c.

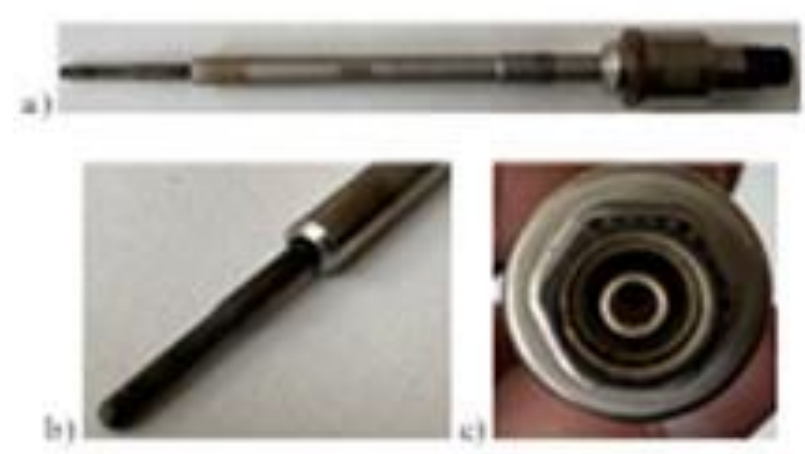

Fig. 3. The failed glow plug from the Opel Insignia 2014 2.0 CDTi engine (source: own elaboration)

\section{Summary}

From the review of literature carried out it is clearly visible that the glow plugs are still the most used in CI engines. The more seldom application of them was found for engines supplied with natural gas, following by these with 
methanol. Recently, there has also been interest in the use of glow plugs in hybrid vehicles.

A lot of attention is paid to the correct position of the glow plug in relation to the injected fuel, due to its influence on exhaust emissions.

It is observed tendency to make probes of glow plugs with smaller diameters and shorter which is conditioned by the limited available space in the combustion chamber of modern diesel engines. Such a limitation is a problem both for diesel engines with a cam valve drive and for the modifications of the cylinder head for the installation of modern electrohydraulic valve drives.

The more and more popular become ceramic glow plugs due to their higher thermal conductivity and an ability to withstand very rapid heating times compared to the other types of glow plugs.
The development of glow plugs with a pressure sensor is very interesting, which, in combination with the control unit, enable optimal combustion and very low engine emissions throughout the engine life cycle. The use of steerable ceramic glow plugs with the parallel use of the glow temperature determination has the potential to further optimizing the glow strategies for cold start applications.

Various numerical and experimental studies on the effect of the application of glow plugs on engine operation were carried out. The experimental ones were conducted on various engines or bombs with constant volume chambers. The malfunctions or damage of any pressure transducer GCS can adversely affect the operation of many modern CI engines.

\section{Nomenclature}

\begin{tabular}{|c|c|c|c|}
\hline $\mathrm{CA}$ & crankshaft angle & FEM & finite element method \\
\hline CDTi & common rail diesel turbo injection & GCS & glow combustion sensor \\
\hline CFR & cooperative fuel research & GPCM & glow plug control module \\
\hline $\mathrm{CI}$ & compression ignition & $\mathrm{HC}$ & hydrocarbons \\
\hline $\mathrm{CM}$ & control module & $\mathrm{HCCI}$ & homogeneous charge compression ignition \\
\hline $\mathrm{CNG}$ & compressed natural gas & NO & nitrogen oxide \\
\hline $\mathrm{CO}$ & carbon oxide & OBD & on-board diagnostics \\
\hline CR & compression ratio & PCM & powertrain control module \\
\hline DI & direct injection & PGI & performance gas injection \\
\hline DPF & diesel particulate filter & SI & spark ignition \\
\hline EGR & exhaust gas recirculation & TDI & turbo direct injection \\
\hline
\end{tabular}

\section{Bibliography}

[1] ABATE, V. Natural gas ignition delay study under diese engine conditions in a combustion bomb with glow plug assist. M.Sc. Thesis, University of Toronto, Toronto 2001.

[2] AESOY, V. Hot surface assisted compression ignition in a direct injection natural gas engine. Ph.D. Thesis, University of Trondheim, Trondheim 1996.

[3] AESOY, V., VALLAND, H. Hot surface assisted compression ignition of natural gas in a direct injection diesel engine. SAE Technical Paper 960767. 1996. https://doi.org/10.4271/960767

[4] AESOY, V., VALLAND, H. The influence of natural gas composition on ignition in a direct injection gas engine using hot surface assisted compression ignition. SAE Technical Paper 961934. 1996. https://doi.org/10.4271/961934

[5] AESOY, V., VALLAND, H. Hot Surface assisted compression ignition of natural gas in a simulated diesel engine environment. SAE Transactions 1996, 105(3), 1022-1030.

[6] AGARWAL, A., ASSANIS, D.N. Multi-dimensional modeling of natural gas autoignition using detailed chemical kinetics. Combustion Science and Technology 2001, 163(1), 177-210. https://doi.org/10.1080/00102200108952155

[7] All about glow plugs. Technical Information No. 04. www.beruparts.eu/support/catalogues/brochures.html (accessed on 04 June 2021)

[8] AMBEKAR, A., BHANGALE, R., CHATTERJEE, R. et al. Glow-plug-assisted combustion of nitromethane sprays in a constant volume chamber. Applied Thermal Engineering. 2015, 76, 462-74.

https://doi.org/10.1016/j.applthermaleng.2014.11.043
[9] ARAKI, M., DONG, H., OBOKADA, T. et al. Characteristics of CNG direct injection with auto-ignition. SAE Technical Paper 2005-26-358. 2005.

https://doi.org/10.4271/2005-26-358

[10] BARTSCH, C. Der neue 1,3-1-Dieselmotor von Fiat. $M T Z$ Motortechnische Zeitschrift. 2003, 64, 374-376. https://doi.org/10.1007/BF03226701

[11] BARTUNEK, B., GOSSE, P., HILGER, U. et al. Entwicklung eines schadstoffarmen Nutzfahrzeugmotors mit Hochdruck-Direkteinblasung von Erdgas für den Einsatz in Stadbussen. Final report of DBU research project 14100, 2004.

[12] BARTUNEK, R., HILGER, U. Direct injection natural gas (DING): a diesel-derived combustion system for low emissions and high fuel economy. SAE Technical Paper 200001-2827. 2000. https://doi.org/10.4271/2000-01-2827

[13] BERUPARTS. www.beruparts.pl/parts/glow-plugs/pressuresensor-glow-plug.html (accessed on 04 June 2021)

[14] BLANC, M., GEIGER, S., HOUBEN, H. et al. DieselKaltstartsystem ISS der zweiten Generation mit Ansaugluft-Vorwärmung. MTZ Motortechnische Zeitschrift. 2006, 67, 352-359. https://doi.org/10.1007/BF03225390

[15] BORGERS, M., HAUSSNER, M., HOUBEN, H. et al. Drucksensor-Glühkerze für Dieselmotoren. MTZ Motortechnische Zeitschrift. 2004, 65, 888-895. https://doi.org/10.1007/BF03227227

[16] BORGQVIST, P., TUNESTAL, P., JOHANSSON, B. Comparison of negative valve overlap (NVO) and rebreathing valve strategies on a gasoline PPC engine at low load and idle. SAE International Journal of Engines. 2013, 6(1), 366-378. https://doi.org/10.4271/2013-01-0902 
[17] BUELTE, H., SCHIFFGENS, H.J., LUTAT, M. et al. Die Neuen Tier-4I-Motoren von Deutz. MTZ Motortechnische Zeitschrift. 2010, 71, 814-821. https://doi.org/10.1007/BF03225627

[18] BURROWS, J., GORETTI, S., RAMOND, A. et al. Glühkerzenintegrierter piezokeramischer Brennraumdrucksensor für Dieselmotoren. MTZ Motortechnische Zeitschrift. 2005, 66, 908-910. https://doi.org/10.1007/BF03226727

[19] CECH, M., KNAPE, M., WILFERT, T. et al. Der abgasfreie Wasserstoff-Kreislaufmotor. MTZ Motortechnische Zeitschrift. 2021, 82, 44-49. https://doi.org/10.1007/s35146-0210645-1

[20] ÇELIK, A., CEVIZ, M.A., YILMAZ, M. et al. Effects of using vortex tubes on events during cold start of a direct injection diesel engine. Journal of Renewable and Sustainable Energy. 2013, 5, 021411. https://doi.org/10.1063/1.4798489

[21] CHENG, S., WALLACE, J. Transient behavior of glow plugs in direct-injection natural gas engines. Journal of Engineering for Gas Turbines and Power. 2012, 134, 92802-1. https://doi.org/10.1115/ICEF2011-60131

[22] Commercial Vehicles and Industrial Applications Glow Plugs. www.beruparts.co.uk/parts/glow-plugs/commercialvehicles-industrial-applications.html (accessed on 04 June 2021).

[23] DENGER, D., MISCHKER, K. Die elektrohydraulische Ventilsteuerung. MTZ Motortechnische Zeitschrift. 2004, 65, 978-987. https://doi.org/10.1007/BF03227236

[24] ENDLER, M. Schlanke Glühkerzen für Dieselmotoren mit Direkteinspritzung. MTZ Motortechnische Zeitschrift. 1998, 59, 98-99. https://doi.org/10.1007/BF03226439

[25] ENGE, C., STERNBERG, R., TSCHIGGFREI, W. Effizienzsteigerung in der Dieselmotoren-Kälteapplikation. $M T Z$ Motortechnische Zeitschrift. 2012, 73, 56-61. https://doi.org/10.1365/s35146-012-0228-2

[26] FABBRONI, M.A., WALLACE, J.S. Flame propagation in natural gas fueled direct injection engines. Proceedings of the Internal Combustion Engine Division Fall Technical Conference, San Antonio 2010. ICEF2010-35182. 2010. https://doi.org/10.1115/ICEF2010-35182

[27] FABBRONI, M.A., WALLACE, J.S. Ignition by shielded glow plug in natural gas fueled direct injection engines. Proceedings of the Internal Combustion Engine Division Fall Technical Conference, Morgantown 2011. 2011, ICEF2011-60085. https://doi.org/10.1115/ICEF2011-60085

[28] FORMAGGIA, L., MICHELETTI, S., SACCO, R. et al. Mathematical modelling and numerical simulation of a glow-plug. Applied Numerical Mathematics. 2007, 57(10), 1125-1144. https://doi.org/10.1016/j.apnum.2006.09.012

[29] GECA, M., BARANSKI, G., MAJCZAK, A. CI engine cold start-up facilitating systems tests. Logistyka. 2015, 3(CD 1), 1451-1458.

[30] Glow Plugs, Glow Plug Controllers and Ignition Coils Catalog. BERU. BorgWagner 2021.

[31] GOERING, C.E., PARCELL, R.T., RITTER, C.P. Hydrated ethanol as a fuel for a DI, CI engine. Transactions of the ASAE. 1998, 41(5), 1255-1260.

https://doi.org/10.13031/2013.17291

[32] GRAGLIA, R., CATANESE, A., PARISI, F. et al. Die neue Dieselmotor-Steuerungvon General Motors. MTZ Motortechnische Zeitschrift. 2011, 72, 134-139. https://doi.org/10.1365/s35146-011-0032-4

[33] HABBAKY, C. A comparative study between circular and elliptical nozzle holes on natural gas combustion and soot formation in a direct injection engine. M.Sc. Thesis, University of Toronto, Toronto 2012.
[34] HANENKAMP, A., TERBECK, S., KOEBLER, S. 32/40 PGI - Neuer Otto-Gasmotor ohne Zündkerze. MTZ Motortechnische Zeitschrift. 2006, 67(12), 932-941. https://doi.org/10.1007/BF03225433

[35] HANULA, B., TAFEL, S., MUECK, A. et al. Schnelllaufender Hochleistungs-Dieselmotor für kleine Flugzeuge. MTZ Motortechnische Zeitschrift. 2003, 64, 286-296. https://doi.org/10.1007/BF03226697

[36] HASEGAWA, M., NISHIZAWA, T., IMAOKA, Y. et al. Improvement of combustion stability under cold ambient condition by mixture control. SAE International Journal of Engines. 2013, 6(2013-01-1303), 1021-1034. https://doi.org/10.4271/2013-01-1303

[37] HAVENITH, C., KUEPPER, H., HILGER, U. Performance and emission characteristics of the Deutz glow plug assisted heavy-duty methanol engine. SAE Technical Paper. 872245. 1987. https://doi.org/10.4271/872245

[38] HEYNE, S., MEIER, M., IMBERT, B. et al. Experimental investigation of pre-chamber autoignition in a natural gas engine for cogeneration. Fuel. 2009, 88(3), 547-552. https://doi.org/10.1016/j.fuel.2008.09.032

[39] HINTERBERGER, C., HOSSFELD, C., OLESEN, M. Simulation der durch Kraftstoffeindampfung unterstützten. MTZ Motortechnische Zeitschrift. 2007, 68, 576-582. https://doi.org/10.1007/BF03227423

[40] HOLZENDORF, S., ALEKSIC-ROESSNER, K., LECHMANN, A. Regelung von Heizverläufen mittels lernender Algorithmen. MTZ Motortechnische Zeitschrift. 2018, 79, 56-61. https://doi.org/10.1007/s35146-017-0195-8

[41] HOUBEN, H., LAST, B., PECHHOLD, F. et al. Glow plug with integrated pressure sensor: a key component for closedloop-combustion control. Proceeding of the Conference: The Operating Process of the Combustion Engine. Graz, 2007.

[42] HOUBEN, H., UHL, G., SCHMITZ, H.G. et al. Das elektronisch gesteuerte Glühsystem ISS für Dieselmotoren. MTZ Motortechnische Zeitschrift. 2000, 61, 668-675. https://doi.org/10.1007/BF03227304

[43] IDZIOR, M. Problems of starting-up in modern diesel engines. Technical Transactions. Mechanics. 2008, 11(105), 7 M, 207-214.

[44] IKEGAMI, M., SHIOJI, M., UMEKITA, K. et al. A glowplug assisted direct-injection diesel engine using lowignitability fuels. Proceedings of the 23rd FISITA Congress. Torino 1990, 905024, 183-191

[45] Installation and fault finding. Denso. www.densoam.eu/products/automotive-aftermarket/ignition/glowplugs/installation-and-fault-finding/ (accessed on 04 June 2021).

[46] KAPPELMAN, P. Method for controlling glow behavior of heater plugs of diesel engine for use in hybrid vehicle, involves operating heater plugs as function of operational parameter of vehicle to restart engine in current operating cycle of vehicle. Patent DE102012204534A1, Germany 2013.

[47] KARSTEN, W., GOY, M., VOM SCHLOSS, H. et al. Vollstrom-brenner zur Partikelfilterregeneration bei mobilen Anwendungen. MTZ Motortechnische Zeitschrift. 2013, 74, 556-560. https://doi.org/10.1007/s35146-013-0168-5

[48] KITA, H., HIRAO, K., HYUGA, H. et al. Chapter $3.2-$ Review and overview of silicon nitride and $\mathrm{Si}-\mathrm{AlON}$, including their applications, In: Handbook of Advanced Ceramics (Second Edition), Ed(s): Shigeyuki Somiya, Academic Press 2013, 245-266.

https://doi.org/10.1016/B978-0-12-385469-8.00015-0

[49] KOLINSKI, K., PSZCZOLKOWSKI, J. The start-up characteristics of 4CT90 engine. Combustion Engines. 2009, 48(SC1), 215-223. 
[50] KROEGER, C.A. A neat methanol direct injection combustion system for heavy-duty applications. SAE Technical Paper 861169. 1986. https://doi.org/10.4271/861169

[51] LI, Q., SHAYLER, P., MCGHEE, M. et al. The initiation and development of combustion under cold idling conditions using a glow plug in diesel engines. International Journal of Engine Research. 2017, 18(3), 240-255. https://doi.org/10.1177/1468087416652266

[52] LINDL, B. Vergleich des Kaltstartverhaltens eines Dieselmotors mit Stahl- und mit Keramikglühkerzen. MTZ Motortechnische Zeitschrift. 1998, 59, 156-159. https://doi.org/10.1007/BF03226445

[53] LINDL, B., SCHMITZ, H.G. Cold-start equipment for diesel direct-injection engines. SAE Technical Paper 199901-1244. 1999. https://doi.org/10.4271/1999-01-1244

[54] MAASSEN, F.J., THOMAS, S. Dieselmotorenentwicklung in Aluminium. MTZ Motortechnische Zeitschrift. 2001, 62, 694-703. https://doi.org/10.1007/BF03226598

[55] MANENTE, V., TUNESTAL, P., JOHANSSON, B. A study of a glow plug ignition engine by chemiluminescence images. SAE Technical Paper 2007-01-1884. 2007. https://doi.org/10.4271/2007-01-1884

[56] MANENTE, V., TUNESTAL, P., JOHANSSON, B. Influence of inlet temperature and hot residual gases on the performances of a mini high speed glow plug engine. $S A E$ Technical Paper 2006-32-0057. 2006. https://doi.org/10.4271/2006-32-0057

[57] MCGHEE, M., SHAYLER, P., LAROCCA, A. et al. The influence of injection strategy and glow plug temperature on cycle-by-cycle stability under cold idling conditions for a low compression ratio, HPCR diesel engine. SAE International Journal of Engines. 2012, 5(3), 923-937.

[58] MERKISZ, J., PIELECHA, J., ANDRYCH-ZALEWSKA, $M$. Influence of the length of a catalyst-coated glow plug on exhaust emissions. Energies. 2020, 13, 6557. https://doi.org/10.3390/en13246557

[59] MUELLER, C.J., MUSCULUS, M.P. Glow plug assisted ignition and combustion of methanol in an optical DI diesel engine. SAE Technical Paper 2001-01-2004. 2001. https://doi.org/10.4271/2001-01-2004

[60] NEAME, G.R., WALLACE, J.S. Bluff-body stabilized glow plug ignition of a methanol fueled IDI diesel engine. SAE Technical Paper 930935. 1993. https://doi.org/10.4271/930935

[61] NGK glow plug types and features. www.yumpu.com/en/document/read/39721252/ngk-glowplug-types-and-features-ngk-glow-plug-types-and-features/ (accessed on 04 June 2021).

[62] NGK glow plugs: 20 questions \& answers. www.partinfo.co.uk/files/Glow\%20Plugs\%20QA.pdf (accessed on 04 June 2021).

[63] OBD-codes. www.obd-codes.com (accessed on 04 June 2021)

[64] OEHLER, G., VOGEL, W., RAUP, M. et al. Der neue V8Dieselmotor von MAN. MTZ Motortechnische Zeitschrift. 2008, 69, 670-679. https://doi.org/10.1007/BF03227478

[65] PAN, K., WALLACE, J.S. Numerical studies of the ignition characteristics of a high-pressure gas jet in compressionignition engines with glow plug ignition assist: Part 1Operating condition study. International Journal of Engine Research. 2017, 18(10), 1035-1054. https://doi.org/10.1177/1468087417699753

[66] PAN, K., WALLACE, J.S. Numerical studies of the ignition characteristics of a high-pressure gas jet in compression ignition engines with glow plug ignition assist: Part 2-Effects of multi-opening glow plug shields. International Journal of Engine Research. 2018, 19(9), 977-1001.

\section{https://doi.org/10.1177/1468087417736997}

[67] PASTOR, J.V., GARCIA-OLIVER, J.M., PASTOR, J.M. et al. Ignition and combustion development for high-speed direct injection diesel engines under low temperature cold start conditions. Fuel. 2011, 90, 1556-1566. https://doi.org/10.1016/j.fuel.2011.01.008

[68] PIELECHA, J., ANDRYCH-ZALEWSKA, M., SKOBIEJ, $\mathrm{K}$. The impact of using an in-cylinder catalyst on the exhaust gas emission in real driving conditions tests of a Diesel engine. IOP Conference Series: Materials Science and Engineering. 2018, 421, 042064. https://doi.org/10.1088/1757-899X/421/4/042064.

[69] PISCHINGER, S., GRUETERING, U., GRAF, M. et al. Entflammung von Dieselkraftstoff bei tiefen Temperaturen. MTZ Motortechnische Zeitschrift. 2008, 69, 52-59. https://doi.org/10.1007/BF03227276

[70] PRAGER, M. Analytische Modellierung des Betriebsverhaltens eines Gasmotors mit neuem Gaszündstrahlverfahren für hohe Leistungsdichte. Ph.D. Thesis, Technische Universität München, München 2010.

[71] Product information automotive glow plugs. Bosch. aa-boschap-uk.resource.bosch.com/media/parts/engine_systems_auto_parts_1/diesel_engine_systems_1/glow_plugs/ pia_glow_plugs_en_58333.pdf (accessed on 04 June 2021).

[72] PSZCZOLKOWSKI, J., KOLINSKI, K. Characteristic of starting rotational speed of self-ignition engine. Biuletyn WAT. 2006, 55(3), 97-112.

[73] PUENTE LEON, F., DEMIRDELEN, I. Drehzahlermittlung mithilfe der Keramikglühkerze als Sensorelement. MTZ Motortechnische Zeitschrift. 2015, 76, 62-67. https://doi.org/10.1007/s35146-014-2049-y

[74] RUDOLPH, F., HADLER, J., ENGLER, H.-J. et al. Der neue 2.01 4V TDI mit Common-Rail. Moderne Dieseltechnologie von Volkswagen. 16 Aachener Kolloquium Fahrzeug- und Motorentechnik. 2007, 21144498, 115-140.

[75] SCHOLL, F. Study of premixed combustion induced by controlled hot surface ignition in stationary gas engines. Ph.D. Thesis. Valladolid/Karlsruhe, 2017

[76] Shedding light on the technical evolution of glow plugs. www.denso-technic.com/shedding-light-on-the-technicalevolution-of-glow-plugs (accessed on 04 June 2021).

[77] Spark plugs \& glow plugs Denso catalogue, 2020.

[78] Steel Glow Plugs. BorgWarner.

www.borgwarner.com/aftermarket/diesel-cold-startignition/steel-glow-plugs (accessed on 04 June 2021).

[79] STEVENS, M. 5 symptoms of a bad glow plug (and replacement cost). July 2020. cartreatments.com/bad-glowplug-symptoms (accessed on 04 June 2021).

[80] SUTEEKARN, R., SACKMANN, M., GUHMANN, C. High-precision, robust cascade model for closed-loop control of ceramic glow plug surface temperature in a diesel engine. Proceedings of the 26th European Conference on Modelling and Simulation (ECMS) 2012, 17054522. https://doi.org/10.7148/2012-0229-0235

[81] TOEDTER, O., LAST, B., ROTTNER, M. et al. Einfluss der Glühtemperatur auf Abgaswerte und Kraftstoffverbrauch von Dieselmotoren. MTZ Motortechnische Zeitschrift. 2011, 72, 894-899. https://doi.org/10.1365/s35146-011-0192-2

[82] WANG, J., YANG, F., OUYANG, M. Dieseline fueled flexible fuel compression ignition engine control based on in-cylinder pressure sensor. Applied Energy. 2015, 159, 8796. https://doi.org/10.1016/j.apenergy.2015.08.101

[83] WLODARCZYK, M.T. Fiber optic-based in-cylinder pressure sensor for advanced engine control and monitoring. Combustion Engines. 2012, 4(151), 3-8.

https://doi.org/10.19206/CE-117016 
[84] WOS, P., JAWORSKI, A., KUSZEWSKI, H. et al. Technical and operating problems yielded from setting up the optimum value of geometric compression ratio in piston engines. Combustion Engines. 2016, 164(1), 3-14. https://doi.org/10.19206/CE-116483

[85] WUNSCH, D., HEYNE, S., VOS, J.B. et al. Numerical flow simulation of a natural gas engine equipped with an unscavanged auto-ignition prechamber. Proceedings of the $3^{\text {rd }}$ European Combustion Meeting Chania, Crete 2007.

[86] YAMAYA, Y., TAKEMOTO, T., FURUTANIM, M. et al. Glow-plug assisted cold start of premixed compression-
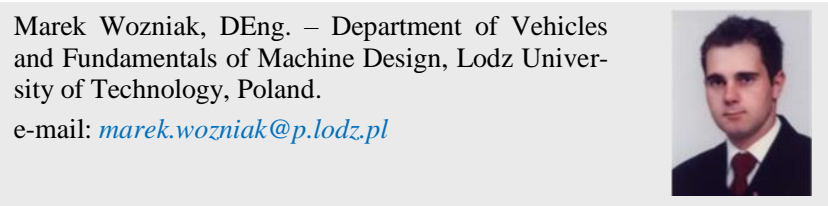

Krzysztof Siczek, DSc., DEng. - Department of Vehicles and Fundamentals of Machine Design, Lodz University of Technology, Poland.

e-mail: ks670907@p.lodz.pl ignition natural-gas engines. Journal of KONES. 2003, 10(12), 303-309.

[87] YAO, C., ZHOU, T., YANG, F. et al. Experimental study of glow plug assisted compression ignition, Fuel. 2017, 197, 111-120. https://doi.org/10.1016/j.fuel.2017.02.008

[88] ZHOU, T., YAO, C., HU, Y. et al. Research on performance and temperature control of glow plugs for PPCI low load assist. IFAC-PapersOnLine. 2016, 49(11), 223-230. https://doi.org/10.1016/j.ifacol.2016.08.034

Prof. Gustavo Ozuna, DSc., DEng. - Department of Industrial Engineering and Systems, University of Sonora, Mexico.

e-mail: gozuna@industrial.uson.mx
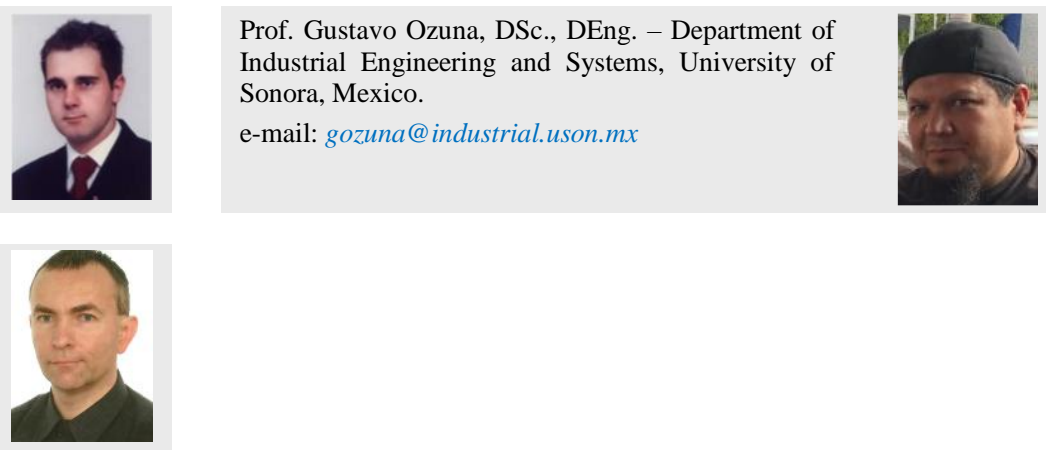